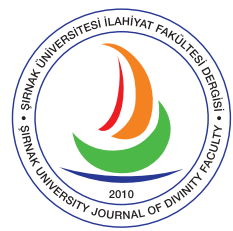

Şırnak University Journal of Divinity Faculty Vol.: 11, Issue: 24, June 2020

e-ISSN 2667-6575

\title{
Din Eğitimi Bağlamında İnsanın Kutsalla İlişkisinin Araçları Olarak İslam Düşüncesinde Bilginin Kaynakları
}

The Sources of Knowledge in Islamic Thought as the Tools of Human Relationship in the Context of Religious Education

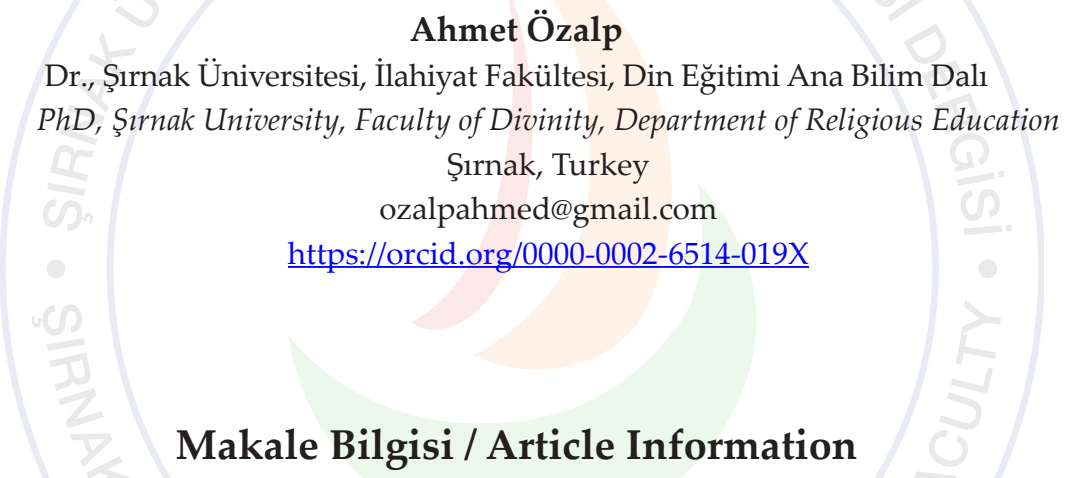

Makale Türü / Article Types: Araştırma Makalesi / Research Article

Geliş Tarihi / Received: 1 Şubat / February 2020

Kabul Tarihi / Accepted: 24 Şubat / February 2020

Yayın Tarihi / Published: 15 Haziran / June 2020

Cilt / Volume: 11 Sayı / Issue: 24 Sayfa / Pages: 42-68

Atıf / Cite as: Özalp, Ahmet. "Din Eğitimi Bağlamında İnsanın Kutsalla İlişkisinin Araçları Olarak İslam Düşüncesinde Bilginin Kaynakları [The Sources of Knowledge in Islamic Thought as the Tools of Human Relationship in the Context of Religious Education]". Şırnak Üniversitesi İlahiyat Fakültesi Dergisi-Şırnak University Journal of Divinity Faculty 11/24 (June 2020), 42-68. https://doi.org/10.35415/sirnakifd.687841

Etik Beyanı / Ethics Declaration: Bu makalede bilimsel araştırma ve yayın etiği ilkelerine riayet edilmiştir. Makale etik izin gerektirmeyen bir çalışma olup en az iki hakem tarafından incelenmiş ve intihal içermediği teyit edilmiştir./ In this article, the principles of scientific research and publication ethics are respected. The article is a study that does not require ethical permission. It has been reviewed by at least two referees and was confirmed that it did not contain plagiarism.

Copyright (C Published by Şırnak Üniversitesi, İlahiyat Fakültesi / Şırnak, Türkiye (Şırnak University, Faculty of Divinity, Şırnak, 73000 Turkey). 


\title{
Öz
}

Kendi üzerine düşünmenin zorunluluğuyla epistemolojik/felsefî bir arka plana gereksinim duyan din eğitimi bu ihtiyacını coğrafyamızın kendi geleneği olan İslam düşüncesinden karşılama imkânnna sahiptir. İslam düşüncesini oluşturan kelâm, İslam felsefesi ve tasavvufun epistemolojik tutumlarının bilginin imkânı, mahiyeti, kaynağı, türleri ve teşekkül süreci gibi bahislerde takip edilmesi mümkündür. Ancak gelenekte ilimlerin teşekkül biçimleri için vazedilen kurallar gereği disiplinimizin, bilgiye mezkûr disiplinlerin perspektifiyle yaklaşamayacağı aşikârdır. Bu durumda din eğitiminin evvela düşünceye değil de düşünceyi üreten akla/saiklere yönelen epistemolojik bir tavır takınarak İslam düşüncesinde bilgiyi üreten gerekçelerle kendi perspektifiyle uyumlu bir buluşma noktası tespit etmesi beklenir. Sonrasında ise bu noktanın disiplin için hangi anlamları açığa çıkardığı incelenmek durumundadır. İslam düşüncesini üreten aklın, bilgiyi Kutsal'a ulaştıran bir vasıta olarak tasvir ettiği görülmektedir. Dolayısıyla insanın Kutsal ile ilişkisini mevzubahis edinen din eğitiminin düşünce mirasımızın ana karakterini oluşturan Aşkın Varlıkla ilişkisellik noktasında buluşması mümkün görünmektedir. Elinizdeki makale bu noktadan hareketle İslam düşüncesinde bilginin kaynakları olarak kabul edilen unsurları din eğitimi açısından insanın Kutsal ile ilişkisini kurma işlevine sahip araçlar olarak sorgulamayı amaçlamaktadır. Buna binaen öncelikle İslam düşünce geleneğini oluşturan kelam, İslam felsefesi ve tasavvufta bilginin kaynakları ele alınacaktır. Sonrasında buradan ve gelenekteki bilginin genel karakterinden yola çıkılarak din eğitiminin kadim mirasımızla nasıl buluşacağı tespit edilmeye çalışılacaktır. En sonunda ise bu kaynakların disiplinimiz için insanın din ile ilişkisini kuran araçlar/kuvveler olarak tasavvur edilebileceği savunulacaktır. Araştırmamız nitel bir çalışma olup yazılı dokümanların incelenmesi yöntemiyle kaleme alınacaktır. Bu doğrultuda konumuzla ilgili İslam düşüncesinde yazılan eserlerin yakın okuması yapılacak, toplanan veriler kavramsal düzlemde ve analitik bir tarzda yorumlanacaktır.

Anahtar Kelimeler: Din Eğitimi, İslam Düşüncesi, Epistemoloji, Bilgi, Bilginin Kaynakları.

\begin{abstract}
Religious education, which requires an epistemological/philosophical background with the necessity of thinking about oneself, has the opportunity to meet this need from the Islamic thought of our geographical tradition. It is possible to follow the epistemological attitudes of kalam, Islamic philosophy and tasawwuf, which constitute Islamic thought, in areas such as the nature, source, types and process of knowledge. It is possible to state that in all of these sciences which represent Islamic thought, knowledge is ultimately accepted as an element that establishes the relationship of man with the Sacred. In this case, it is possible for religious education, as a discipline that deals with the relationship of man with the Sacred, to meet at the point of "relationality" with the Transcendent Being, which expresses the main characteristic of the knowledge in our thought heritage. With this point in mind, this article aims to question the elements considered as sources of knowledge in Islamic thought as tools that have the function of establishing the relationship of man with the Sacred in terms of religious education. First of all, we will try to determine how religious education will meet with our ancient heritage, as mentioned above, and then the sources of knowledge in theology, Islamic philosophy and tasawwuf, which form the tradition of Islamic thought. In our study, it will be argued that these sources of knowledge can be envisioned as "the faculty that establish the relationship of man with the Sacred" from the perspective of our discipline.
\end{abstract}

Keywords: Religious Education, Islamic Thought, Epistemology, Knowledge, Sources of Knowledge. 


\section{Extended Abstract}

Religious education, which requires an epistemological/philosophical background with the necessity of thinking about oneself, has the opportunity to meet this need from the Islamic thought of our geographical tradition. It is possible to follow the epistemological attitudes of kalam, Islamic philosophy and mysticism (tasawwuf), which constitute Islamic thought, in areas such as the nature, source, types and process of knowledge. Yet, it is obvious that our discipline will not be able to approach knowledge from the perspective of knowledge disciplines, as required by the rules for the formation of sciences in tradition. The basic rule determined for the sciences in terms of this subject is the following: It is natural that disciplines other than the above sciences, which are accepted as Kullî (universal), also adopt the phenomenon of knowledge. However, they can never directly examine the issues such as the possibility, source, and value of knowledge while they are considering and developing knowledge from their perspective. Any discipline, other than those accepted at the highest level in the classification of sciences, cannot address such complex issues as such and question them with this aspect. Thus, other disciplines should consider them already existing and to prove them in a small but particular way with a problematic perspective specific to their principles. This can be done by taking appropriate opinions about the subject.

In this case, religious education is expected to find a meeting point compatible with its own perspective, by adopting an epistemological attitude towards the mind/motives that produce thought rather than the thought itself. Then, it should examine what meanings this intersection reveals for the discipline. Both the information conception prior to the establishment of the Islamic thought atlas and the knowledge approaches of Islamic sciences show that knowledge was designed as a means of relation with the Sacred. Ibn Mas'ud's interpretation of science as "knowledge about God and his actions" shows that the understanding of Islamic knowledge during the first era was of this nature. According to Ghazali, the concept of knowledge, which was later used to cover information about other things, was removed from the essence of its soul meaning over time. Nevertheless, it is still possible to follow the traces of this holiness on the background of the theories of kalam, Islamic philosophy and tasawwuf.

It seems clear that the function of information in the word, which sees the information as a means of conveying it from the shahid (from visible) to the gaib (invisible), is to transmit it to the field of transcendent beings. The situation is similar in Islamic philosophy, which sees the most genuine information as the knowledge acquired by the human mind by acquiring (merging) with the intellect in act. Since tasawwuf is a matter bestowed on the human heart, knowledge already has a completely mystical structure. Therefore, it is suitable to state that in all these sciences which represent Islamic thought, knowledge is ultimately accepted as an element that establishes the relationship of man with the Sacred. In this case, it is possible for religious education, as a 
discipline that deals with the relationship of man with the Sacred, to meet at the point of "relationality" with the Transcendent Being, which expresses the main characteristic of the knowledge in our thought heritage.

With this point in mind, this article aims to question the elements considered as sources of knowledge in Islamic thought as tools that have the function of establishing the relationship of man with the Sacred in terms of religious education. First of all, within this framework we will try to determine how religious education will meet with our ancient heritage, as mentioned above, and then the sources of knowledge in kalam, Islamic philosophy and tasawwuf, which form the tradition of Islamic thought. To summarize, these are the external senses (five sense organs), true news (mass transaction news and the news of the Prophet) and reason. In Islamic philosophy, the forces of perception are again external senses (five sense organs), The internal senses and reason. There are also five forces of internal senses, namely common sense/sensus communis, the (faculty of) imagination, the (faculty of) estimation, the retentive faculty, and the cognitive faculty. In tasawwuf, the source of information is the heart.

In our study, it will be argued that these sources of knowledge can be envisioned as "the faculty that establish the relationship of man with the Sacred" from the perspective of our discipline. However, among all these powers of perception, it is only the cognitive faculty power, reason and heart that can establish the relationship of man with God directly from the internal senses. The other remaining sources of information correspond to the indirect means of communication of man. Religious education does not have to choose, prioritize, or construct a hierarchical subordinate relationship between them, due to its perspective. This is because, when it comes to a multi-faceted being like a human, it can be said that any of these sources alone cannot produce a true relationship with knowledge and religion. Therefore, the discipline's attitude is to accept all of them as monolithic elements that reveal different faculty of man to encompass all aspects of human relationship with religion. On the contrary, a shattering and distinctive view poses the risk of absolute (acceptance) of any of these tools, which it is obvious that such a view cannot fully understand the person fully. The absolutization of the mind implies a positivist, while the alienation of the cognitive power implies the imagination of a dreamer person. Accepting the heart as the one and only sometimes means the formation of human typologies that develop completely speculative knowledge and behavior. The only way for a person to realize her/his existence in all aspects is to keep all these faculties functioning in a coordinated manner as a whole.

Our research is a "qualitative" study and will be written using the written document analysis method. Within this framework, the basic sciences of Islamic thought about our subject, the works written in kalam, in the philosophy of Islam and in tasawwuf will be read closely, and the collected data will be interpreted in a conceptual and "analytical" manner. 


\section{GİRIŞ̧ ${ }^{1}$}

Her disiplin kendisini oluştururken felsefi/epistemolojik arka planını keşfetmeye muhtaçıı. Teşekkülü bakımından henüz genç bir disiplin olan din eğitimi de gerek teorik, gerekse pratik meselelere ilişkin güzergâhını belirginleştirmek adına -ilk elden- bilgiye taalluk eden esaslarını temin etmek durumundadır. Bu esasların kendisinden iktisap edileceği yaklaşımlar -doğal olarak- disiplinin hangi düşünce mirasından besleneceğiyle ilgilidir.

Elinizdeki yazı İslam düşüncesinin bilgi telakkilerini esas alarak din eğitimi için bir takım muhtemel epistemolojik istinat noktalarını sorgulamayı hedeflemektedir. İslami mefkûrenin tarafımızca tercih edilmesinin en baskın gerekçesi üretilen her yeni düşüncenin o coğrafyanın kendi kültürel mirasını esas alması gerektiğine dair inancımızdır. Bu inanç "hiçbir düşüncenin kendisini var eden ve hayatiyetini sürdürmesini sağlayan toplumu ve tarihsel gerçeklikleri aşacak kudrette olmadığ ${ }^{\prime \prime}{ }^{2}$ kanaatinden beslenmektedir. Dolayısıyla İslam düşüncesine olan yönelimimiz bu anlamda tercihten ziyade bir zorunluluğu da ima eder.

Bu tercihin bir diğer sebebi bir bütün olarak addedildiği takdirde kadim mirasımızın alanımız için bilginin kaynaklarını olduğunca çeşitlendirebilme fırsatı sunmasıdır. En aslî konusunu insan olarak belirlemiş̧ ${ }^{3}$ bir disiplin için bu çeşitliliğin insanı daha geniş bir skaladan tasvir etme

\footnotetext{
Bu çalışma “Din Eğitiminde Bilgi Problemi” başlıklı doktora tezi esas alınarak hazırlanmıştır. / This article is extracted from doctorate dissertation entitled "The Knowledge Problem in Religious Education" (PhD Dissertation, Marmara University, İstanbul/Turkey, 2020).

2 M. Cüneyt Kaya, "Önsöz", İbn Sînâ'nın Mirası, mlf. Dimitri Gutas (İstanbul: Klasik Yayınlar1, 2010), 16-19.

3 Beyza Bilgin, Eğitim Bilimi ve Din Eğitimi (Ankara: Gün Yayıncılık, 2007), 27-28; Bayraktar Bayraklı, İslam'da Eğitim (İstanbul: y.y., 2002), 17, 21; Muhammet Şevki Aydın, Din Eğitimi Bilimi (Kayseri: Kimlik Yayınları, 2017), 9, 28; Nurullah Altaş - İsmail Arıcı, “Din Eğitiminin Bilimselleşme Süreci", Din Eğitimi, ed. Mustafa Köylü- Nurullah Altaş (İstanbul: Ensar Neşriyat, 2014), 70.
} 
imkânı sağladığı açıktır. Bununla birlikte İslam düşüncesinden günümüze kadar aktarıla gelen bütün bilgi tasavvurlarını takip etme olanağından mahrum olduğumuz ortadadır. Bu mahrumiyet aynı zamanda din eğitimi için epistemolojik esasların yekpare bir biçimde sınırları önceden belirlenmiş bir makaleye sığdırılmasının olanaksızlığı için de söz konusudur. Dolayısıyla disiplin için "epistemolojik esasların tayini" söylemi çalışmamız tarafından arzu edilen uzak vadeli bir maksada tekabül etmektedir.

Böylece makalenin hususî amacı İslam düşüncesini teşkil eden kelâm, İslam felsefesi ve tasavvuf ilimlerinde bilginin kaynakları olarak kabul edilen unsurların din eğitimi perspektifinden yorumlanması olarak belirginleşmektedir. Ancak bundan önce yapılması beklenen, disiplinimizin bu unsurlara hangi sorgulama biçimleri ve hangi veçhelerle yönelebileceğinin tespitidir. Zira İslami gelenekte -en azından- felsefî müdevven ilimler (disiplinler) için vazedilmiş birtakım kaideler vardır. ${ }^{4}$ En öz ifadeyle kabul şudur: "Bir disiplinin istinat ettiği tümel ilkeler o disiplinin alanı ve sınırları dâhilinde kanıtlanamaz." Bu durumda ilimler kavramsal temellerini kendi iç örgülerinin dışna çıkıp daha küllî disiplinlere müracaat ederek bulma yoluna gider. ${ }^{5}$ Problematiğini keşfetmeye çalışan bir disiplin olarak din eğitiminin İslam ilimlerinin teşekkül biçimlerinin vazettiği tarzda bir ilim olarak kabul edilmesinin yolu onun ancak düşünce mirasımızda hudutları tayin edilmiş bu çerçeveye hangi gerekçelerle dâhil olabileceğinin belirlenmesi ile mümkündür.

$\mathrm{Bu}$ amaca binaen yukarıdaki kaide din eğitimi için düşünüldüğünde epistemolojik bir arayışın öznesi olarak disiplinimizin; bilginin imkânı, mahiyeti, türleri ve teşekkül süreçlerini mutlaklıklarıyla konu edinemeyeceği açığa çıkar. Aksi bir tutum felsefe ile bir alt kademede epistemolojinin sınırlarının ve tikel disiplinlerin tümel ilkelerini daha küllî bir üst alandan almasıyla ilgili zorunluğun ihlâli anlamına gelir. $\mathrm{O}$ halde din eğitiminin -kendi ilkelerinin gerekli kıldığı bağlantıların dışında olmak kaydıyla-

${ }_{4}$ Buradaki maksadımız din eğitiminin felsefi bir disiplin olduğunu ve/veya felsefenin altında konumlanması gerektiğini iddia etmekten uzaktır. Ancak din eğitimi için "felsefi bir arka plan arayışı" söylemi, tek başına, kendisinden önce bir felsefi düşüncenin varlığını ve bu düşüncenin disiplin için düşünsel bir zemin oluşturabileceğini ima eder. Bu söylem, mahiyet ve içerik olarak, din eğitimi ile felsefenin başka şeyler olduğunun ve nazarî veçhesiyle din eğitiminin, bir nevi "küll-cüz"' ilişkisi bağlamında felsefenin altında konumlanabileceğin baştan kabulüdür. Ayrıca epistemolojik bir sorgulamanın ürünü olan makalemiz için doğal olan, onun yine bu epistemolojik kuralların tayin ettiği sınırlara riayet etmesidir. Dolayısıyla felsefi/burhânî ilimler için belirlenmiş sınırlardan hareketle bir perspektif yakalama çabası din eğitiminin burhânî, beyânî veya irfânî bir temelde kabulüne matuf görülmemelidir. Buradaki yegâne amaç din eğitimi ile İslam düşüncesi arasında bir buluşma noktası tespit etme adına asgarî seviyede felsefenin en azından cüz'i ilimler için vaz ettiği ilimler arasındaki ilişkilerin bir de disiplinimiz için tasavvur edilmesidir.

5 İlhan Kutluer, Yitirilmiş Hikmeti Ararken (İstanbul: İz Yayıncılık, 2011), 488-499; Ömer Türker, "Mukaddime'de Aklî İlimler Algiss:İbnHaldûn'un 'Bireysel Yetenekler' Teorisi", İslam Araştırmaları Dergisi 15 (2006), 35, 37. 
"bilgi nedir", "bilginin kaynağı ve türleri nelerdir", "bilgi nasıl teşekkül eder" gibi mutlak sorgulamaları disiplinin iç problematiği dâhilinde cevaplamaya teşebbüs edemeyeceği söylenebilir. Onun yapabileceği şey bu soruların cevaplarını üst kademelerde addedilen diğer ilimlerin ürettiği düşüncelerden seçip onları kendi perspektifiyle temellük etmektir. Öyleyse peşine düşülmesi beklenen soru şudur: Epistemolojik bir arka plan edinmek adına din eğitimi İslam düşüncesini temsil eden kelâm, İslam felsefesi ve tasavvufun ürettiği bilgi yaklaşımlarından/kavrayışlarından hangilerini, hangi surette ve nasıl bir tutumla temellük edebilir?

Üretilebilecek başka cevapların ihtimalini de göz ardı etmemekle beraber bir başlangıç olarak çalışmamızın bu soruya önerdiği yanıt şudur: İslam düşüncesindeki bilgi kavrayışları ile din eğitiminin perspektifinin kesiştiği noktanın veya noktaların tespit edilmesi ve bu müşterek noktanın kavramsallaştırma (1stılâhlaştırma, terimleştirme) yoluyla disipline mal edilmesi. ${ }^{6}$ Burada meselenin Câbirî'ye ait "epistemolojik araştırmanın konusu düşünsel üretimin kendisi değil, düşünsel üretim araçlarıdır"7 şeklindeki tespit ile birlikte ele alınması yerinde olacaktır. Bunu da dikkate alarak konu açılacak olursa epistemolojik esasları tayin etmesi için din eğitiminin kadim mirasımızda üretilen düşüncelerin kendisine değil, bu düşünceyi üreten "akla/saiklere/gerekçelere" yönelmesi beklenir. Disiplinin epistemolojik tutumunun sınırlarını ve keyfiyetini belirleyecek olan müşir, bu ilkedir.

$\mathrm{Bu}$ ilkenin işaret ettiği sınırlara riayet etmek adına takip edilmesi

\footnotetext{
${ }^{6}$ Sonyıllarda dineğitimindeyapılanşu kavramsal çalışmalar zikredilmeye değerdir:Muhammed Muhdi Gündüz, Niyet Kavramının Din Ĕ̆itimi Açısından İncelenmesi (Gazzâlî Örneği) (Mardin: Şırnak Üniversitesi Yayınları, 2019), 194-251; Muhammed Muhdi Gündüz, “Niyet Kavramı ve Din Eğitimi Açısından Anlam Katmanları", Siirt Üniversitesi Illahiyat Fakültesi Dergisi 6/2 (2019); Ahmet Özalp, Din Eğitimi Açısından Dâvûd el-Kayserî́de İnsan Kavrayışı (İstanbul: Marmara Üniversitesi, Sosyal Bilimler Enstitüsü, Yüksek Lisans Tezi, 2014); Ahmet Özalp, “Dâvûd elKayserî Açısından Din Eğitiminde Bir Dönüşüm Hâdisesi Olarak Karanlık ve Aydınlık", IV. Türkiye Lisansüstü Çalışmalar Kongresi Bildiriler Kitabı-V (Felsefe-Eğitim-Illetişim), ed. Hümeyra Dinçer - Ümit Güneş (İstanbul: y.y., 2015), 4/179-194; Nurgül Bulut, Din Eğitiminin İmkân ve Sinırlılkları Açısından Mizâc Kavramı (İstanbul: Marmara Üniversitesi, Sosyal Bilimler Enstitüsü, Yüksek Lisans Tezi, 2013); Nurgül Bulut, "Evrensel Ahlâkın Ontolojisi; 'Öteki'de İçerlenmiş Ben", II. Uluslararası Dini Araştırmalar ve Küresel Barı̧ Sempozyumu (b.y.: y.y., 2016), 1/234-253; Hatice Fakioğlu Bağcı, Dewey ve Gadamer'in 'Tecrübe' Anlayışlarının Din Eğitimi Açısından Felsefi Olarak İncelenmesi (İstanbul: Marmara Üniversitesi, Sosyal Bilimler Enstitüsü, Doktora Tezi, 2019); Z. Şeyma Arslan, Fitrat Kavramı Çerçevesinde Eğitimde 'İnsanın Neliği Sorusu' (İstanbul: Marmara Üniversitesi, Sosyal Bilimler Enstitüsü, Doktora Tezi, 2006); Elif Batman, Din Eğitimi Açısından Hikmet Kavramı (İstanbul: Marmara Üniversitesi, Sosyal Bilimler Enstitüsü, Yüksek Lisans Tezi, 2016); Veysel Altun, Din Eğitimi Açısından İnsanın Yetkinliği (Sadreddin Konevî Örneği) (İstanbul: Marmara Üniversitesi, Sosyal Bilimler Enstitüsü, Doktora Tezi, 2020); Feyza Başkan, Din Ĕ̆itimi Açısından Gazzâlì’de Bağlanma Kavrayış̧ı (İstanbul: Marmara Üniversitesi, Sosyal Bilimler Enstitüsü, Yüksek Lisans Tezi, 2018).

7 Muhammed Âbid el-Câbirî, Tekvinül-Aklil-Arabî: Arap Aklının Oluşumu, çev. İbrahim Akbaba (İstanbul: İz Yayıncilık, 1997), 19.
} 
beklenen zihnî süreç öncelikle fikir geleneğimizin bilgi bahsinde ürettiği düşüncelerin hangi saiklerle veya hangi akılla ortaya çıtığını incelemek, sonrasında din eğitiminin perspektifini de dikkate alarak disiplinimizin bu düşüncelerin arkasında yatan gerekçelerden hangisiyle veya hangileriyle buluşabileceğini tespit etmektir. Meseleyi açılığa kavuşturmak ad1na burada izlenecek yol evvela İslam düşüncesinde bilginin kaynakları olarak kabul edilen unsurların kısaca aktarılması olacaktır. Sonrasında hem bu unsurların genel karakterinin hem de topyekûn bir bakışla İslam düşüncesinde üretilen bilgi telakkilerinin üzerine kurulduğu arka plan tespit edilmeye çalışılacaktır. Bu yapılırken ilk kullanımından günümüze kadar bilginin karakteristik olarak Kutsal ile ilişkinin bir aracı olarak tasavvur edildiği gözlemlenmeye çalışılacaktır. İslam düşüncesinde üretilen bilgi kavrayışlarının bir arka planı olarak kabul edildiğinde bu karakterin din eğitimini İslam düşüncesiyle buluşturmasının imkânları aranacaktır. Akabinde ise din eğitiminin hangi perspektifle bu düşünsel zeminde buluşabileceğinin imkânı üzerinde durulacak ve buradan hareketle disiplinimiz için bilginin kaynaklarının "insanın din ile ilişkisini kuran araçlar" olarak yorumlanacaktır. Makalemiz nihai olarak bütün bu bilgilerin bizi ulaştırdığı neticenin ele alındığı bir sonuçla noktalanacaktır.

\section{1. İSLAM DÜŞÜNCE GELENEĞİNDE BİLGİNIN KAYNAKLARI}

Bu başlıkta sonradan kaleme alınacak hususlara temel teşkil etmesi amaciyla sırasıyla İslam düşüncesini oluşturan kelâm, İslam felsefesi ve tasavvuf ilimlerinde bilginin kaynakları olarak kabul edilen unsurlar özet bir tarzda ele alınacaktır. Dolayısıyla mümkün olduğunca söz konusu ilimler arasındaki veya herhangi bir ilmin kendi içerisindeki tartışmalardan uzak durulacaktır. Ancak bütün bu ilimlerdeki düşüncelerin takibinin imkânsızlığı sebebiyle yer yer bazı sınırlandırılmalara başvurulacaktır. İslam felsefesinde genel kanaati temsil ettiği kabul edilen Meşşâi gelenek ile İşrâkî gelenek tercih edilecektir. Meşşâi gelenekten Kindî, Fârâbî ve İbn Sînâ ile İşrâkî gelenekten ekolün kurucusu olan Şihabüddîn Yahya esSühreverdî ile yetinilecektir. Tasavvufta ise genel düşünceyi ifade ettiğine kanaat edilen ilk dönem hâkim sûfî düşünceyle kifayet edilecektir. Kelâm ilminde ise sınırlandırılmaya muhtaç bırakmayacak şekilde bir takım genel kabullerin varlı̆̆ sebebiyle herhangi bir kısıtlamaya gidilmeyecek, konu mezhepler arasındaki tartışmalar göz ardı edilerek incelenecektir.

Kelâm ilmi beş harici duyuyu, aklı ve ilaveten doğru haberi (el-haberü'ssâdıkı) bilginin kaynağı olarak kabul etmiştir. ${ }^{8}$ Haberin bir bilgi kaynağ 1

8 Bk. Ebû Bekr Muhammed İbn Fûrek, Mücerred makalâti'ş-Şeyh Ebil-Hasan el-Eş̧arî, thk. Daniel Gimaret (Beyrut: Dârü'l-Meşrik, 1986), 10-33; Ebû Mansûr el-Mâtürîdî, Kitâbü't- 
olarak addedilmesinin nedeni muhtemelen vahiy ve Hz. Peygamber'den gelen diğer bilgilerin de doğru bilgi edinme yollarından sayılması amac1na yöneliktir. Çünkü kelamcllar doğru haberden, daha çok mütevâtir haber ve Hz. Peygamber'den nakledilen haberleri anlamaktadırlar. ${ }^{9}$ Mütekellime göre yanılma ihtimalleri saklı tutulmakla beraber duyular ile diğer kaynaklar olan doğru haber ve akıl üçlüsü vasitasıyla gerçeğe uygun doğru bilgiye ulaşmak mümkündür. ${ }^{10}$ Kelâmi literatürde doğru haber ikiye ayrılır: Mütevâtir haber ve mucize ile müeyyed resuller (kendisine kitap indirilmiş peygamberler)' in haberleri. ${ }^{11}$

İslam felsefesinde ise bilginin kaynakları olarak kabul edilen unsurlar âlemin mertebeleri ve insanın bu mertebelerin her birisinden aldığı bilgilerin teşekkül sürecine göre şekillenmiştir. Birçok filozof idrak ve bilgi edinme süreçlerinin hissî algı yoluyla başladığını savunur. Bu süreçler haricî bilginin duyusal algı yollarıla insana intikal etmesiyle başlar. Bu mertebede oluşan suret (imaj) maddî duyu ve duyusal idrak ile oluşur. Bu bilginin sureti zahirî ve maddîdir. İdrak süreçlerinin birinci basamağı olan bu mertebeye hissî idrak veya mahsûsat idraki denir. İkinci mertebe ise ilmi suretlerin tahayyül edilme aşamasıdır. Bu mertebede insan zihni edinmiş olduğu suretleri maddeden soyutlar ama bu soyutlama henüz tam değil, nisbîdir. Üçüncü ve son mertebe olan tam ta'akkul mertebesi ise suretin, maddeden tamamen soyutlanması aşamasıdır. ${ }^{12}$

Bu üç aşamadaki her bir bilgi; his, misâl ve akıl şeklinde isimlendirilen üçlü âlem tasnifindeki kısımlardan birine tekabül eder. Birincisi kuvve ve madde âlemidir ki buna dair bilgiler hissî idrak yoluyla gerçekleşir. İkincisi ise

Tevhîd, thk. BekirTopaloğlu - Muhammed Aruçi, (Ankara: TDV İSAM Yayınları, 2018), 8388; Ebû Bekr el-Bâkıllânî, Temhîdül-evâil ve telhisü'd-delâil, thk. 'İmadüddin Ahmed Haydar (Beyrut: Müessesetü'l-Kütübi's-Sekâfiyye, 1986), 28-34; Abdülkâhir el-Bağdâdî, Usûlü’d dîn (Beyrut: Dârü'1-Kütübi'1-İlmiyye, 1981), 8-9; Ebü'1-Yüsr el-Pezdevî, Usûlü'd-dîn, thk. Hans Peter Linss (Kahire: Dâru İhyai'l-Kütübi'l-Arabiyye, 1963), 6; Sa'düddîn et-Teftâzânî, Şerhü̈ akâidi'n-Nesefiyye (Karaçi: el-Büşra, 2015), 58; İsmail Hakkı İzmirli, Yeni İlm-i Kelâm, haz. Sabri Hizmetli (Ankara: Umran Yayınları, 1981), 33-35; Hasan Hüseyin Tunçbilek, “Bilgi Kaynağ1 Olarak Haber-i Sâdık", Harran Üniversitesi İlahiyat Fakültesi Dergisi 5 (2006), 95.

9 Hanifi Özcan, Mâtürîdî'de Bilgi Problemi (İstanbul: İFAV Yayınları, 1998), 74.

${ }^{10}$ M. Sait Özervarlı, "Alâeddin el-Üsmendî'nin Kelâmcıllğı ve Bilgi Teorisi: Mâverâünnehir Kelâm Düşüncesine Bir Katkı", İslam Araştırmaları Dergisi 10 (2003), 49-50; Tunçbilek, "Bilgi Kaynağı Olarak Haber-i Sâdık", 95.

${ }^{11}$ Teftâzânî, Şerhü̈l-akâid, 67-79; Tunçbilek, "Bilgi Kaynağ1 Olarak Haber-i Sâdık", 106. Mâtürîdî genelin aksine haberi mütevâtir haber ve vâhid haber olmak üzere ikiye ayırır. (Mâtürîdî, Kitâbü't-Tevhîd, 85-86.) Bağdâdî'ye göre ise bazı kelâmcılar haberi üçe ayırır: Mütevâtir, âhâd ve bazı hükümlerinde tevâtür gibi olan ikisinin ortası haber. Mütevâtir haber uydurulması mümkün olmayan haberdir ki zarurî ilmi (kat'i ilmi) gerektirir. Âhâd haber ise metni aklen müstahil olmayıp isnadı sahih ise ameli gerektirir ama kat'i bilgi ifade etmez. (Bağdâdî, Usulü'd dîn, 12-13.)

${ }^{12}$ Seyyid Muhammed Hüseyin et-Tabâtabâî, Şerhu bidâyeti'-hikme, thk. Muhammed Mehdi el-Mü'min (y.y.: Mektebetü'1-Fikr, 1422/2001), 2/237-238. 
madde ve hissî âlemden soyutlanmış ama hala onun eserlerini taşıyan misal âlemidir ki buna karşılık gelen bilgi tahayyüldür. Üçüncüsü ise maddeden ve eserlerinden tamamen soyutlanmış akl âlemidir ki bu âlem ta'akkul (akletme) ile bilinir. ${ }^{13}$ Felsefede işte bu bilgi edinme süreçlerinin gerçekleşmesini sağlayan üç bilgi kaynağı vardır: ${ }^{14}$ Dış duyular, iç duyular ve akı1..$^{15}$

Dış duyu algıları felsefecilerin üçlü varlık tasnifindeki maddî âleme tekabül eden hissî âlem hakkında bilgi verir. Tabiatı itibariyle bu duyular maddî olana yakın, eşyanın hakikatine ve akledilir mahiyetine uzaktır. Öznenesne ilişkisine dayandıkları için de bu bilgiler tümüyle duyu organlarına ve fizikî dünyaya muhtaçtır. Bu sebeple duyularla kesp edilen bilgiler aslında henüz maddî olandan soyutlanmış olmayıp aklî kavram olmaktan uzaktır. Dolayısıyla bu veriler aklî bilgiler gibi değişmez olmadığından hiçbir zaman varlığın mahiyeti ve hakikati hakkında doğru/mutlak bilgi veremez. Ancak akıl tarafından teyit edilmesi durumunda bu bilgiler itibar kazanabilir. ${ }^{16}$

İnsanın bilgi edinme süreçlerinin ikincisi bâtıni (içsel) duyularla gerçekleşen algilardır. Hem Meşşâî hem İşrâkî gelenekte nefsin bâtıni güçleri de dış duyular gibi beştir: Bunların birincisi el-hissü'l-müşterektir (ortak duyu). Bu duyu mahsûsatın (hissedilir şeylerin) suretini idrak eder, ancak onu depolamaz. İkincisi bu suretleri muhafaza eden, yani depolayan duyudur ki buna el-hayâl (suret-taşıyıcı güç) denir. Üçüncüsü el-vehmdir

13 Tabâtabâî, Şerhu bidâyetil-hikme, 239-240.

${ }^{14}$ Bazı felsefeciler bilginin küllî ve cüz'î olmasından yola çıkarak bilginin kaynaklarını ikiye indirirler. Esası itibariyle böyle bir tasnif ile tarafımızca tercih edilen üçlü tasnif arasında bir fark yoktur. Meselâ bilginin kaynaklarını iki temel hususa indirgeyen Kindî’ye göre alg1 iki türlüdür: Aklî ve hissî. Çünkü varlık küllî ve cüz'îlerden oluşur. Maddî ve cüz'î şeyler duyularla algılanır. Maddî bir varlığı olmayan küllî cins ve türler ise insanî nefsinin tam bir kuvvesi olan akılla algılanır. Bu düşünceye sahip felsefeciler aslında bizim dış ve iç olarak ikiye ayırdığımız duyuları tek bir başlık altında toplamışlardır. Bk. Ebû Yûsuf Ya'kûb b. İshâk el-Kindî, "Kitâbün fi felsefeti'l-'ûlâ", Risâletü'l-Kindî el-felsefiyye, thk. Muhammed Abdülhâdî Ebû Rîde (Kahire: Dârü'l-Fikri'l-Arabi, 1950), 107.

${ }^{15}$ Felsefecilerin akıl, beş duyu ve haberin bilgi ifade etmesi hususunda kelamcılardan tamamen farklı düşündükleri söylenemez. Ancak felsefeci burada kelamcılar gibi bizatihi bilginin dış dünyadan edinilme biçimlerini değil sonraki süreçleri önemsemiştir. Daha açık bir ifadeyle felsefe bilginin tam soyutlanma halini yani taakkül durumunu dikkate alır/hedefler. Diğer algılar ve bu algıların gerçekleşme biçimleri felsefede sadece akla bilgi sağlayan araçlar ve süreçler olarak görülür. Dolayısıyla hükümde etkin olan akıldır. Ancak bu, İslam filozoflarının aklı mutlaklaştırdığı anlamını taşımaz. Çünkü aklın bu bilgiye ulaşacak yetkinliğe sahip olması onun ancak maddeden soyutlanıp aşkın bir varlıkla -yani faal akılla (Hz. Cibril)- ittisâline bağlıdır. Yani felsefe her ne kadar bu bilgileri kabul ediyor olsa bile bunları dış dünyadan aktarılan veriler olarak değerlendirmekte ve onların akılda tam bir tecerrüd (soyutlanma) ile gerçekleşmesine eğilmektedir. Bu sebeple kelamcı doğru haberi kat'î bilgi olarak değerlendirirken filozoflar onu zannî ve iknâî bir kategoride kabul etmektedir. Cağfer Karadaş, “Birleşen ve Ayrışan Yönleriyle Kelâm İlminin Usûl-i Fıkıh, Tasavvuf ve İslâmFelsefesi ile Olan İlişkisi", İslâm Düşüncesinin Kurucu Unsurları: Usûl-i Fıkıh, Kelâm, Tasavouf ve İslâm Felsefesi (Tartışmalı İlmî İhtisas Toplantısı) (2016), 36-37.

${ }^{16}$ Kindî, "Kitâbün fi felsefeti'l-'ûlâ", 106-107. 
(vehim gücü). Bununla cesaret, cimrilik gibi zahirî duyu organlarının algılayamadığı soyut ve cüz'î anlamlar idrak edilir. Dördüncüsü el-hâfizedir (hafıza gücü). Bu duyu vehim gücünün idrak ettiği cüz'î anlamları depolar. Beşincisi ise el-mütesarrife (dönüştürme gücü veya dönüştüren güç) duyusudur ki bu da suret ve manaları ayırıp birleştirir. ${ }^{17}$

Özetlersek bu beş iç duyudan sadece üçü yani müşterek his, vehim ve mutasarrife güçleri bilgi alabilmektedir. Geriye kalan hayal ve hafıza güçleri ise sadece birer depo görevi görür. Müssterek hissin aldığı bilgi dış dünyaya aittir. Vehim gücü ise sevgi, nefret gibi soyut şeyleri nasıl tecrübe ettiğimiz ve bu şeylerin sonucunda nasıl davranış geliştireceğimize ilişkin bilgileri sağlar. Yani bu bilgi de müşterek hisle edinilene benzer bir şekilde aslında fizik dünyadan mükteseptir. Bu durumda elimizde bizi aşkın âlem hakkında bilgilendirme potansiyeline sahip, mistik olarak tanımlanmaya aday olabilecek bilgiyi sağlayan iki alıcı kalmaktadır ki bunlar da duyuların sonuncusu olan mutasarrife ve aşağıda ele alacağımız akıldır. ${ }^{18}$ Ancak ister dış, ister iç duyu organlarıyla edinilsin ta'akkul edilmeden (akıl tarafından işlenmeden) bu veriler hala nihaî hakikatine ulaşmamış cüz'î bilgilerdir. ${ }^{19}$

Felsefeye göre bilgi edinme yollarının üçüncüsü olan akıl veya akıllar Yaratıcı'nın izniyle varlık hakkında tasarrufta bulunan, yaratılanlarda tesir eden, cisme taalluk etmeyen kadim ve mücerred cevherlerdir". ${ }^{20} \mathrm{Bu}$ tanım aslında insanî akıldan çok semâvî akılları tanımlıyor görünmektedir. Çünkü felsefeye göre insan aklının varlık hakkında tasarrufta bulunmak veya

\footnotetext{
${ }_{17}$ Muhammed 'Alî, 'Akdül-ferâid 'alâ Şerhil-'Akâid (Karaçi: El-Büşra, 2015), 60-61; Seyfüddîn el-Âmidî, Ebkârül-efkâr, thk. Ahmed Muhammed Mehdi (Kahire: Dârü'l-Kütüb ve'1Vesâiki'l-Kavmiyye, 2002), 1/108-109; Ebü'l-Fütûh Şihâbüddîn Yahyâ b. Habeş esSühreverdî, "el-Elvâhüll-'imâdiyye" Mecmua-i musannefât-i Şeyhli İşrâk, thk. Necefkulî Habibî (Tahran: Pejûheşgâh-1 Ulûm-i İnsânî ve Mütâla'ât-i Ferhengi, 2001), 51-52. Metinde kullanılan kavramların parantez içerisine alınan Türkçe karşılıkları M. Cüneyt Kaya tarafından çevrilen Dimitri Gutas'ın “İbn Sînâ'nın Mirası" isimli eserinden alınmıştır. Bk. Dimitri Gutas, İbn Sînâ'nın Mirası, çev. M. Cüneyt Kaya (İstanbul: Klasik Yayınları, 2010), 173-174. Ayrıca mezkûr bâtınî duyulardan bazılarının kimi yerlerde farklı isimlerle anıldığı görülmektedir. el-hayâl kavramı bazen el-musavvire el-hâfize ise el-zâkire olarak isimlendirilmiştir. Bu iki kavramın tesmiyesindeki farklılıklar lafzîdir. Yani bu farklılık aynı şeyin sadece muhtelif şekillerde isimlendirilmesinden kaynaklanmaktadır. Makalede herhangi bir kavram kargaşasına yol vermemek adına bu iki duyu için elhayâl ve el-hâfize kavramları kullanılacaktır. Ana metinde de zikredileceği gibi sonuncu bâtınî duyu olan el-mütesarrife gücünün de bazen el-müfekkire bazen de el-mütehayyile olarak isimlendirildiği görülmektedir. Ancak buradaki farklılık lafzî olmaktan ziyade anlamsaldır. Çünkü mütesarrife güç akıl tarafından kullanıldığında el-müfekkire, vehim gücü tarafından kullanıldığında ise el-mütehayyile olarak tesmiye edilir. Bu sebeple mutasarrife güç söz konusu olduğunda yerine göre bu anlamlar da gözetilecek ve yer yer diğer isimler de kullanılacaktır.

18 Gutas, İbn Sînâ'nın Mirası, 175.

19 Ömer Türker, İbn Sinnâ'da Metafizik Bilginin İmkânı (Ankara: TDV Yayınları, 2019), 65.

20 'Alî, 'Akdül-ferâid 'alâ Şerhil-'Akâid, 81-82.
} 
yaratılanlarda tesir etmek gibi bir yetkinliği yoktur. İnsan aklı söz konusu ise Kindî'nin "varlığın hakikatini kavrayan basit bir cevher" 21 şeklindeki tanımının daha açı olduğu söylenebilir. ${ }^{22}$

İç ve dış duyular, duyulur şeylere yönelir onları idrak eder. Aklın bilgisi ise -bilakis- soyut ve maddî olmayan kavramlar, küllîler, ezelî ve apaçı hakikatler gibi akledilir şeylere dairdir. ${ }^{23}$ Yani duyular tikel bilgilere, akıl ise tümellere yönelir. Ayrıca duyusal verilerin neticesinde zihinde, kendisiyle temasa geçilen varlığın bir sureti oluşurken aklî idrak sonucunda zihinde böyle bir imaj oluşmaz. Akıl aslında bu tikelleri bir araya getirerek tümeller oluşturur. Kindî’ye göre akıl, böylece tikelden tümellere ulaşmak suretiyle aşkın âleme, tersine bir istikametle de, yani tümelden de tikele inerek, maddî varlıklara ilişkin bilgi edinme yetisine sahiptir. ${ }^{24}$ Ancak insan aklının tam ta'akkul seviyesine çıkması için onu henüz sürecin başındaki bil kuvve halinden çıkaracak bir etkene ihtiyacı vardır. Çünkü bil kuvveden bilfiile çıkan her şeyin bir muharrike (hareket ettirene) ihtiyacı vardır. Felsefede insan aklını bilfiil duruma çıkaran şey faal akıldır. ${ }^{25}$

Sûfîler ise her anlam derecesini algılayacak farklı bir idrak gücünün olması gerektiğinden yola çıkarak bilginin kaynaklarını incelerler. Başka deyişle farklı bir anlam derecesi veya tarzından bahsetmek onu anlayabilecek muhtelif bir idrak gücünü de kabul etmek anlamına gelir. ${ }^{26}$ Bilgiyi zâhir ve bâtın (ilim-marifet) katmanlarında ele alan ilk dönem tasavvuf ehli işte bu kabulden hareketle idrak güçleri bahsinde kelâm ve diğer disiplinlerin kabul ettiği unsurlarla yetinmemiş bunlarla birlikte kalb ve kalbi oluşturan sadr, kalb, fu'âd ve lübb gibi güçleri de saymışlardır.

${ }^{21}$ Kindî, "Risâletü'l-Kindî fi hudûdi'l-eşyâ'i ve rusûmihâ" Risâletü'l-Kindî el-felsefiyye, thk. Muhammed Abdülhâdî Ebû Rîde (Kahire: Dârü'l-Fikri'l-Arabi, 1950), 165.

22 'Alî, 'Akdü̈l-ferâid 'alâ Şerhil-'Akâid, 81-82.

${ }^{23}$ Gutas, İbn Sinnâ'nın Mirası, 175.

${ }^{24}$ Kindî, Felsefî Risaleler, çev. Mahmut Kaya (İstanbul: Türkiye Yazma Eserler Kurumu Başkanlığı, 2015), 40. Kindî’nin akıl ve aklın taksimi ile ilgili görüşleri için bk. Kindî, Felsefî Risaleler, 39-42.

${ }^{25}$ Ebû Alî Hüseyn b. Abdillâh b. Alî İbn Sînâ, de Anima, thk. Fazlurrahman (Durham: University of Durham, 1970), 235. İslam felsefesinde insan aklını heyûlanîden melekeye, melekeden de tam fiile çıaran şeye faâl akıl denir. Bk. Fahrüddîn er-Râzî, Şerhül-İşârât ve't-tenbîhât: Felsefe, tabi'iyyât, ilahiyyât ve 'îrfân, thk. Ali Riza Necefzade (Tahran: Encümen-i Asar ve Mefahir-i Ferhengi, 2005), 270. Bu anlayışa göre kâinattaki bütün bilgiler semâvi veya aklî diye tesmiye edilen ezelî akıllarda, bu akılların akledilenleri sürekli düşünmesi yoluyla depolanmaktadır. İnsan aklı ise bu akılların sonuncusu olan faâl akılla temasa (ittisâla) geçerek bu makulata ulaşabilmektedir (Gutas, İbn Sînâ'nın Mirası, 175). Hem Meşşâi hem de İşrâkî gelenekte faal akıl olarak tesmiye edilen şey aslında şer'î lisandaki Hz. Cebrâil'dir (Bilal Kuşpınar, İbn Sina'da Bilgi Teorisi (İstanbul: MEB Yayınları, 1995), 130). Onu bir "nur" olarak görmesine rağmen Sühreverdî de bu aklı yine Hz. Cebrâil anlamında Ruhu'l-Kudus olarak adlandırır (Sühreverdî, "el-Elvâhü'l-îmâdiyye", 88).

${ }^{26}$ Hakîm et-Tirmizî, Beyânül-fark beyne's-sadr ve'l-kalbve'l-fu'âd vel-lüb, thk. Nicholas Lawson Heer (Kahire: Dâru İhya'i'l-Kütübi'l-Arabiyye, 1958), 7. 
Kalb İlâhî hitabın mahalli ve muhatabı, ma'rifet ve irfân denilen tasavvufî bilginin kaynağı, keşf ve ilhâm mahallii ${ }^{27}$ şeklinde tanımlanır. Sûfîlerin kalb dedikleri şey bedendeki fizikî kalple bir biçimde ilişkili olmakla birlikte onun dişında sûfîlerin rûhânî ve Rabbânî latif bir varlık olarak değerlendirdiği bir idrak aracıdır. O; insanın idrak eden, bilen, ârif tarafı olarak kabul edilmiştir. ${ }^{28}$

İlk dönem sûfîleri arasında kalbi en mufassal ve sistemli bir biçimde ele alan Tirmizî onu dört katmana sahip bir yapıda tasvir eder. Dışarıdan içeriye doğru bunlar sadr, kalb, fu'âd, lübb şeklinde sıralanır ve bunların her biri kendisinden sonra gelen için bir perde ve siper konumundadır. Bu durumda "kalb" kelimesi hem bu bütünün, hem de ikinci katmanın adıdır. ${ }^{29}$ Kalbin biri melekût, diğeri şehadet âlemine açılan iki kapısı vardır. Şehadet âlemine açılan kapı diş duyulara açılan kapıdır ${ }^{30} \mathrm{ki}$ bu da kalbin dış cephesini oluşturan sadrdır. Kalp ise genel anlamdaki kalbin ikinci durağıdır. Tirmizî onu evin içi gibi tasvir etmiştir. $\mathrm{O}$, sadr ile ilişkisi bakımından kalbi pınara, sadrı ise bu pınardan akan suyun biriktiği havuza benzetir. Bu durumda sadr bilgilerini bazen dışarıdan, bazen de içeriden (kalpten) alır. Fu'âd ise üçüncü katmandır. Nasıl ki kalp sadrın ortasındaysa, fu'âd da kalbin ortasında yer alır. Tirmizî onu ma'rifet, havâtır, görme ve müşâhede etmenin yeri olarak tasvir eder. Ancak o sadece görür, bu görüntüleri işleyip bilgiye dönüştüren kalptir. Yani gören fuâd olmakla birlikte bilen yine kalptir. Ancak fû́ad görmediği sürece kalp bilgiden yararlanamaz. Kalbin en iç kısmında ise gözdeki nur gibi fu'âdın görmesini sağlayan lübb bulunur. ${ }^{31}$

Sonuç olarak İslam düşüncesini oluşturan ilimler muhtelif unsurları bilginin kaynağı olarak kabul etmiştir. İnsanın bilme yollarını çeşitlendirme imkânı sağlayan bu ihtilaflar bir yandan da insanın Kutsal ile ilişkisinin yollarını zenginleştirme fırsatı tanır. Bir bütün olarak tasavvur edildiğinde dış duyular, iç duyular, akıl ve kalbin her biri beşerin, Yaratıcısıyla münasebetlerinin farklı veçhelerine tekabül eder. Bu anlamda diş duyular gâibe ulaşmanın şâhid mertebesini oluştururken; kelamî anlamda akıl bu şâhid ile gâib arasındaki taalluku sağlayan bir vasıta görevi görmektedir. İnsanın içkin bilme imkânlarına tekabül eden bâtınî idrak güçleri ise akla, oradan da faal akla ulaşmanın bir orta basamağı görümündedir. Felsefî in-

\footnotetext{
${ }^{27}$ Süleyman Uludağ, "Kalp", Tasavouf Terimleri Sözlüğ̈̈̈ (İstanbul: Kabalcı Yayınc1lık, 2012), 205.

${ }^{28}$ Ebû Hamid Muhammed b. Muhammed el-Gazzâlî, İhyâ'u 'ulûmi'd-dîn (Beyrut: Dârü'lMa'rife, 1983), 3/18-19; Gündüz, Niyet Kavramının Din Eğitimi Açısından İncelenmesi, 167.

${ }^{29}$ Tirmizî, Beyânül-fark beyne's-sadr ve'l-kalbve'l-fu'âd ve'-lüb, 33-34, 38.

${ }^{30}$ Gazzâlî, İhyâ, 3/21.

31 Tirmizî, Beyânül-fark beyne's-sadr ve'l-kalbvel-fu'âd ve'-lüb, 35-36, 38, 46, 48, 53, 58, 59, 62, 68, 70,72 .
} 
san aklı ve sûfî kalbi ise aşkın alanla doğrudan temasa geçme kabiliyetine sâhip hususlar olarak tasvir edilmiştir.

\section{2. İSLAM DÜŞÜNCE GELENEĞİNDE İNSANIN KUTSALLA İLIŞKISIINI KURAN BİR HUSUS OLARAK BİLGí}

İslam düşünce geleneğinde bilgiye ilişkin kavrayışları üreten aklın, başka bir deyişle epistemolojik yaklaşımların arka zeminindeki gerekçenin, tespiti tarihten bugüne tevarüs ettiğimiz bilginin bu düşüncedeki ana karakterinin tahkik edilmesiyle mümkün görünmektedir. Epistemolojik tavrın da gerektirdiği şekilde din eğitiminin bu tarihî mirasla buluşma aralığının tayini böyle bir okumaya muhtaç görünmektedir. Dolayısıyla gerek İslam düşüncesinin ilk adımlarını oluşturan müdevven ilimler öncesi dönemin bilgi algısı, gerekse teşekkülünden sonra ilimlerin bilgi bahsinde yoğunlaştığı hususlar bizim için bu meseleye dair ipuçları barındıran olgular olarak kabul edilecektir. Takip edilecek güzergâh İslam'ın ilk asırlarında bilgiye ait tasavvurlar ile İslam düşüncesini oluşturan kelâm, İslam felsefesi ve tasavvufun bilgi kuramlarının temerküz ettiği bilgiye ilişkin ortak noktanın/noktaların metinlerden takip edilmesi olacaktır.

Gazzâlî’nin yaptığı tahkike göre bilgiyi ifade eden en başat kavram olan ilim kavramı İslam'ın ilk dönemlerinde tamamen dinî bir karaktere sahipti. Ona göre ilk asırlarda Müslümanlar bu kavramı Allah ve Allah'ın yarattıklarına dair eylemlerine ilişkin bilgiyi ifade etmek için kullanıyordu. Bunun en göze çarpan örneklerinden birisi Hz. Ömer vefat ettiğinde İbn Mes'ud'un “ilmin onda dokuzu öldü" sözüdür. İbn Mes'ud sonradan bu cümledeki ilim kelimesini "Allah ve onun eylemleri hakkındaki" bilgi olarak açıklamıştır. Gazzâlî’ye göre sonradan bu kullanımın dışına çıkılarak ilim kavramı başka şeyler hakkındaki bilgiye de teşmil edilmiştir. ${ }^{32} \mathrm{Bu}-$ nunla birlikte -ilim geleneğimizdeki kavrayış tarzlarına bakıldığında- İslam düşünce tarihinde bilginin Aşkın Varlık'la ilişkisinin güçlü bir biçimde sürdürüldüğünü iddia etmek yine de zor değildir. Bilginin bu kabiliyetini İslam düşüncesini temsil eden kelâm, İslam felsefesi ve tasavvuf eserlerinin her birinden açıça takip etmek mümkündür.

Kelâmla başlanacak olursa, bu disiplinde bilginin kendisinin doğrudan ya da dolaylı bir ilişki aracı olarak tasvir edildiği rahatlıkla müşahede edilebilir. İlim-malum (bilen-bilinen) arasındaki ta'alluk ile ilgili tartışmalar buna işaret etmektedir. Şöyle ki çoğunluğu kelâmcılardan oluşan bazı âlimlere göre ilimde, âlim ile malumun irtibatını kuracak bir araç gereklidir ki bu izafe ile âlim bu malumun âlimi, malum da bu âlimin malumu olabilsin. Bu

${ }^{32}$ Gazzâlî, İhyâ'u 'ulûmi'd-dîn (Beyrut: Dârü'l-Erkâm b. Ebi'l-Erkâm, 1998,) 1/51. 
araca ta'alluk denir. Mütekellim ekseriyetle bu ta'allukun ilmin kendisi olduğunu savunur. Geriye kalanlar ise taalluk âlimiyettir -yani âlim olma durumudur- der. ${ }^{33}$ İlk görüşe göre bilen ile bilinenin münasebetini kuran şey bilginin kendisidir. Yani bir bakıma ilim bizâtihi ilişkinin kendisidir. İkinci görüşe göre ise ilim bilen ile bilinenin arasındaki irtibatın kendisi değil, bu irtibatın sonucudur. Bu durumda ilim malumla -doğrudan değilse bile- dolaylı olarak bir ilişki vasıtasıdır demek yerinde olacaktır.

Bu ilişkinin İlâhî karakteri ise kelamın epistemolojik yaklaşımında ortaya çıkmaktadır. Mütekellimin, kendilerinden önceki düşünsel/felsefî yaklaşımlardan farklı bir şekilde (doğru haberin içinde) vahyi, bilginin bir

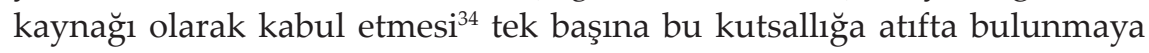
kâfidir. Ancak bu bilgi türü bir nevi ulvî olandan süflî olana (yukarıdan aşağıya) doğru seyreder. Yaratıı' nın kulla kurduğu temas olan vahyin nüzĥl (inme) olarak ifade edilmesinin anlamı budur. Bununla birlikte kelâm epistemolojisinde, insanın Mutlak Varlık'la irtibatı tek taraflı nüzûl hâdisesiyle sınırlandırılmamış, bir de "urûc" (yukarıya çıkma, yükselme) olarak tesmiye edilebilecek bir tasavvurla insan da bu ilişkiye ortak ve taraf kılınmıştır. Bilgi bahsinin temelini teşkil eden şâhidden gâibe (görünenden görünmeyene) ${ }^{35}$ tabiri insanın bu pozisyonunu tasdik edebilecek kelamî bir ifade gibi görünmektedir.

Kelamcılar varlığı şâhid ve gâib olmak üzere ikiye ayırmaktadır. Mevcûdâtın bu şekilde taksimi kelamcıları görünmeyen varlık alanını görünenden yola çıarak temellendirmeye sevk etmiştir. Bu durumda görünene ilişkin insan bilgisi görünmeyene ait bilginin esasını teşkil etmektedir. Zihinsel olarak görünenden yola çıkarak ispat edilen görünmeyen varlığın da bir dış gerçekliğine ulaşılır. ${ }^{36}$

Gâibe götüren bir bilgi olarak şahid bu bağlamda aslında aşkın varlık alanına ilişen bir yapı arz eder. Öyleyse dinî değeri anlamında şâhidgâib bilgisi birbirinden soyutlanabilecek iki bilgi türüne tekabül etmez. Bu ikisinin tefrik edildiği cihet sadece karşılık geldikleri ontolojik alanların farklılı̆̆ itibariyledir. Hatta Özcan'a göre Mâtürîdî’de dinî bilgi bir bakıma (böyle bir ayrım mümkünse eğer) genel bilgiye mündemiç bir tarzdadır. Çünkü âlemü̈l-gaybı (gayb âlemini) ve Yaratıcı'yı bilmenin yegâne yolu şehadet âleminin O'na delalet etmesidir. Başka bir deyişle gâibi bilmede

\footnotetext{
${ }^{33}$ Muhammed b. 'A'la b. Ali el-Fârûkî el-Hanefî et-Tehânevî, "Ilm", Keşşâfu istilâhâti'l-fünûn (Beyrut: Dârü'-Kütûbi'l-İlmiyye, 1998), 349.

${ }^{34}$ Teftâzânî, Şerhül-'akâid (Karaçi: el-Büşra, 2015), 67-79; Tunçbilek, “Bilgi Kaynağ1 Olarak Haber-i Sâdık", 106.

35 Özervarlı, "Alâeddin el-Üsmendî'nin Kelâmcllı̆̆1 ve Bilgi Teorisi: Mâverâünnehir Kelâm Düşüncesine Bir Katkı", 49.

${ }^{36}$ Özervarlı, "Alâeddin el-Üsmendî'nin Kelâmcllı̆̆1 ve Bilgi Teorisi: Mâverâünnehir Kelâm Düşüncesine Bir Katkı", 49.
} 
esas olan dış dünyadır ve bu bağlamda şâhid gâibin varlığının bir ayetidir. Eğer şâhidî bilgimiz hakikate ulaştırmayacaksa bütün bildiklerimiz izafi bir değere sahip olur ki o zaman bilginin ve imanın dinî değeri de kalmaz. ${ }^{37}$

İslam felsefesinde de durum bunun benzeridir. Maddeye yakın, manevî varlık alanına uzak oldukları için dış duyuların sağladığı bilgilere yeterince ihtimam göstermemeleri İslam filozoflarının daha işin başında bilginin metafizik alanla irtibatına ilişkin koydukları tavrın kıstaslarından birisidir. Bir diğer idrak gücü olan akla gelindiğinde bu düşünce daha da berraklaşır. Yukarıda da zikredildiği gibi bazı filozofların aklı "yaratıcı'nın izniyle varlık hakkında tasarrufta bulunan, yaratılanlarda tesir eden, cisme taalluk etmeyen kadim ve mücerred cevherler" şeklinde bir nevi semâvî aklı tarif eder gibi tanımlaması onların akla yüklediği melekût âlemiyle ilişki kurma kabiliyetinin bir diğer göstergesi olarak kabul edilebilir. Böylece akıl, İslam felsefesinde insan ile meleklerin iştirak ettiği bir mefhuma delalet eder. Klasik felsefedeki on akıl teorisini mukarrebîn meleklerle özdeşleştiren İslam felsefesi insan aklını da bunlarla ittisâl kurma kabiliyetine sahip bir yetkinlikte konumlandırır. Bu akılların onuncusu ve felsefe terminolojisinde "faal akıl" olarak adlandırılan -yukarıda da zikredildiği gibi- Hz. Cibril veya Sühreverdî'nin tesmiyesiyle Ruhu'l-Kudus'tur. İnsan aklı işte bu faal akıldan insan nefsine feyz edilmiştir. ${ }^{38} \mathrm{Bu}$ yaklaşıma göre faal akıldan südûr etmesi itibariyle insan aklı da zaten semâvî bir karaktere sahiptir ve bu yetkinliği sayesinde semâvî âlemle ittisâl imkânı yakalar.

İttisâl anlayışı İslam felsefesinde insan aklının aşkın varlık alanıyla ilişkisine delalet eden bir kavramdır. Bu anlayış tek başına İslam felsefesi açısından insanın Kutsal ile olan ilişkisini temellendirmeye kâfidir. Zira ittisâl insanın aklını bilginin zemini görmekle beraber, kaynak olarak faal akla göndermede bulunur. İnsan, amelî pratiklerle beraber sarf ettiği entelektüel çabaların nihayetinde bu akılla iletişime geçerek ondan küllî ma'kûlâtı edinir. ${ }^{39}$

Aklın ittisâl yeteneği İslam felsefesinde insanın Aşkın Varlık ile ilişkisinin imkânına delalet eder. Bundan dolayı filozofların "düşünen (akıllı) canlı" şeklindeki tanımıyla insan kendinde veya fizik âleminde düşünen bir varlıktan ziyâde Mutlak'ı tanımak üzere yaratılmış bir varlık mefhumuna tekabül eder. Öyleyse insan olmak aslında kendini aşmak, aşkın varlıkla bütünleşmektir. Bilmek ise Faal Akıl yoluyla mevcûdâtı teşkil eden her şeyin yegâne kaynağı olan Zât-ı İlâhi'yi Nihaî gerçeklik olarak bilmek demektir. ${ }^{40}$

İslam düşüncesinin son halkasını oluşturan tasavvufun bilgi yaklaşımı da buna benzer bir keyfiyette aşkın alandan feyiz yoluyla tahakkuk eder.

${ }^{37}$ Özcan, Mâtürîdî'de Bilgi Problemi, 20.

38 'Ali, Akdül-ferâid 'ala Şerhi'-'Akâid, 81-82.

${ }^{39}$ İbn Sînâ, de Anima, 248-249.

${ }^{40}$ Seyyid Hüseyin Nasr, Bilgi ve Kutsal, çev. Yusuf Yazar (İstanbul: İz Yayıncılık, 1999), 14. 
Sûfî epistemolojisi bilgi edinme hususunda insanı, mükemmel bir yetkinlikte görmez. Ancak İslam felsefesinde insanı bilgiye hazırlayan daha çok entelektüel çaba iken; sûfî mefkûresinde bu, amelî pratiklerdir. Tasavvufta amelî pratikler sonucunda Allah'ın lütfuyla kalbe ilkâ edilen bilginin kavramsal ifadesi olan ma'rifet tamamen aşkın varlık alanıyla ilişkinin bir tezahürü olarak tasvir edilmiştir. Bu kavramın sûfîlerce "Allah hakkında sahih hâl" olarak muhtevalandırılması, ${ }^{41}$ hâlin de vehbî bir çerçevede değerlendirilmesi bunun apaçık bir göstergesidir. Vehbîliği münasebetiyle bu tür bilgiler insan kesbinin kendisine doğrudan dahlinin olmadığı bir yapı arz eder. Terminolojik ifadeyle insan-Allah ilişkisinde bilgi Mutlak Yaratıcı olarak bütünüyle Allah'ın tasarrufundadır. Hâliyle insanın idrak kuvveleri birer vasıta olmakla birlikte bilginin varlık illeti (var oluş sebebi) değildir. Başka bir tabirle bilgi eylemenin bir sonucu olmakla birlikte, eylem sûfî epistemolojisinde bilginin vücuda çıkmasının doğrudan gerekçesi değildir. ${ }^{42}$

Nihai olarak tasavvufta bilgi Aşkın Varlık veya varlıklardan (melekler) feyiz yoluyla kalbe bahşedilir. Yukarıdan aşağıya bir seyir takip etmesiyle birlikte bu bilginin temel karakteristiği müteâl varlık alanıyla temasın sonucunda hâsıl olmasıdır. Tasavvufta aklın yerine kalbin ikame edilmesinin gerekçesi de budur. Zira bilgi denilince ma'rifet, keşf, ilhâm gibi vehbî bilgileri anlayan ve yakîn ifade etmeleri hususunda bunlara en büyük payeyi uygun gören sûfîlere göre noksanlık, fakr gibi muhtelif sebeplerden dolayı aklın bu bilgilere ulaşma kabiliyeti yoktur. ${ }^{43}$ Onlara göre insanın müteal varlık alanıyla ilişkisini kurma yeteneğine sahip uzuv kalptir.

Hülâsa, ilk vahiyden İslam fikir atlasının tekâmülüne, oradan da günümüze kadar süregelen düşünce mirasımızda bilgi İlâhî bir tarzda ve İlâhî Varlık ile irtibata geçebilecek bir surette karakterize edilmiştir. Bilgi kendisi kutsala ulaşabileceği gibi insanı kutsala ulaştırabilecek bir yeteneğe de sahiptir. ${ }^{44}$ Ancak bu, bilginin mutlak mahiyetinden kaynaklanan bir yetiden ziyade İslam dininin doğasının bir sonucudur. ${ }^{45}$ Başlığın başından beri açığa çıkarmaya çalıştığımız düşünce budur. Epistemolojik tavrın yöneldiği düşüncenin arka planı veya düşünceyi üreten vasıtaların, saiklerin bilgi özelinde bizi ulaştırdığı nokta İslam düşüncesi için Allah ile ilişkidir. Aşikârdır

${ }^{41}$ Ebül-Hasen Alî b. Osmân b. Ebî Alî el-Cüllâbî el-Hücvîrî, Keşfül-mahcûb, thk. İs'ad Abdülhâdi Kındil (Beyrut: Dârü'n-Nehdati'l-Arabiyye, 1980), 509; Ekrem Demirli, Sadreddin Konevî́de Bilgi ve Varlık (İstanbul: İz Yayıncllık, 2005), 48.

${ }^{42}$ Hücvîrî, Keşfül-mahcûb, 431-432.

${ }^{43}$ Muhammed b. İbrâhim el-Kelâbâzî, et-Ta'arruf li mezhebi ehli't-tasavouf, thk. Ahmed Şemsüddîn (Beyrut: Dârü'l-Kütübi'l-İlmiyye, 2001), 69; Hacı Bayram Başer, Şeriat ve Hakikat: Tasavvufun Teşekkül Süreci (İstanbul: Klasik Yayınları, 2017), 194.

${ }^{44}$ Nasr, Bilgi ve Kutsal, 13.

${ }^{45}$ Hasan Hanefi, "Müslüman Aklının Eleştirisi ya da İslam düşüncesinin Yeniden İnşası", Uluslararası İslâm Düşüncesi Konferansı 2 (İstanbul: İstanbul Büyükşehir Belediyesi Kültür İşleri Daire Başkanlığı Yayınları, 1997), 119. 
ki mahiyetleri, keyfiyetleri, tesmiyeleri ve değerleri muhtelif olmakla birlikte İslami epistemolojide bilgiyi üreten düşüncenin arkasındaki aklın nihai olarak yöneldiği yegâne şey Mutlak Hakikat'tir. İslam düşüncesini üreten bu aklın tasvir ettiği ontolojik ilişkiler ağı üç kutuplu bir yapıdadır: Allah, insan ve tabiat. Bu kutupları önemlerine binaen ikiye indirgemek istediğimizde daha belirgin olarak karşımıza Allah-insan ilişkisi çıkar. Yani doğa bu ağın üzerine temerküz ettiği esasî kutuplardan biri olmaktan çıkar, silikleşir. Çünkü tabiat bizzât kendisi için teveccüh gören bir varlık alanını temsil etmez. O; Allah tarafından insanlığa müsahhar kılınmış bir eşyaya tekabül ederken, insan cihetinden Allah'a ulaşmanın bir tür vasitası ve köprü görevi görmektedir. Bu düşüncede doğaya insanın Allah'ı bulması için yardımcl bir rol verilmiştir. Allah'ın ayetlerinden biri olan doğa buna göre aklın Yaratıcı'ya ulaşmasını sağlayan bir unsur olarak tevzif edilmiştir. ${ }^{46}$

\section{DIN EĞITTIMININ İSLAM DÜŞÜNCESIYYLE BULUŞMA NOKTASI OLARAK “KUTSAL'LA İLİ̧SISSELLIK"}

Bir disiplinin meseleler/olgular hakkında konuşmasının yegâne yolu kavramlardır. Kavramların bir disipline mal edilmesinin yolu ise o kavramın istılah (terim) hâline getirilmesidir. Din eğitiminin de takip etmesi beklenen yol budur. Dolayısiyla o, ya mevcut kavramları kendi perspektifinin gerektirdiği sorulara tabi tutarak yeninden muhtevalandıracak ya da daha önce kullanılmamış kelimeleri kendi açısından içeriklendirerek kavramsallaştıracaktır. Bir başlangıç noktası olarak İslam düşüncesindeki kavramlara yönelecek olursak karşılaşılacak mesele şudur: Din eğitimi bu kavramlara/kavrayışlara hangi soru veya soruları yönelterek onları kendi perspektifinden yorumlama ve dolayısıyla temellük etme imkânı bulabilir? Epistemolojik açıdan söyleyecek olursak bilgi bahsindeki mevcut kavram ve kavrayışlar nasıl bir sorgulamaya tabi tutularak din eğitimi için yeninden muhtevalandırılabilir?

Yukarıda da ifade edildiği gibi din eğitiminin bu kavramlara mutlaklığı dâhilinde sorular soramayacağı açıktır. Öyleyse göz önünde bulundurulması gereken husus mutlaklığı değil de mukayyedliği (şartlılığı) çerçevesinde din eğitiminin yönelteceği soru veya soruların açığa çıkarılmasıdır. Çalışmamızın bu mukayyed perspektif için önerisi din eğitiminin İslam düşüncesiyle buluşma noktasın ibraz eden "insanın Kutsal Varlık'la kapsamlı bir ilişkiselliği" dir. Yani din eğitiminin teveccüh göstereceği cihet İslam düşüncesindeki bilgiye ilişkin mülahazaların insanın Zât-ı Bârî̀yle ilişkisini kurmasıdır. Bu durumda disiplinimizin bütün bu kavram, kavrayış ve düşüncelere yönelteceği sorunun şu şekilde kabul edilmesi mümkündür: "Bu kavramın/kavrayışın/düşüncenin vs. insanın Aşkın Varlıkla ilişkisini kurmadaki işlevi nedir?"

${ }^{46}$ Câbirî, Arap Aklının Oluşumu, 40-41. 
İslam düşüncesinde üretilen bilgi yaklaşımlarının temel karakteristiği de onun, insanın bu ilişkisini kurma kabiliyetine sahip olmasıdır. Dolayısıyla epistemolojik tavrın "düşüncenin kendisine değil de onu üreten saiklere/ araçlara/akla yönelmesi gerektiği" şeklindeki telkine de uygun bir biçimde din eğitiminin gelenekle bilgiye dair düşünceyi üreten bir saik olarak "kutsal ile ilişki" arka planında buluşması mümkün görünmektedir. Başka bir ifadeyle en temelde bilginin imkânını, mahiyetini, kaynaklarını ve türlerini sorgulayan epistemoloji tarihte üretilen düşüncenin kendisini değil o düşünceyi üreten gerekçeleri (ve/veya aracı, aklı, saikleri) inceler. Bunu İslam düşüncesine uyguladığımız takdirde bilgiye yönelik düşünceleri üreten bir saik ve gerekçe olarak "Allah’a ulaşma arzusu"ndan söz edilebilir. Din eğitiminin sağlamaya çalıştı̆̆ şey de budur: İnsanın din ve dinin sahibi ile ilişkisini kurmak. ${ }^{47}$ Dolayısıyla İslam düşüncesi ve din eğitiminin arka planını oluşturan söz konusu ilişki bu ikisinin buluşma noktasını ifade etmek için epey uygun görünmektedir. Epistemolojik bağlamda İslam düşüncesiyle ilişki arka planında buluşan din eğitimi için geriye kalan; gelenekteki bilgi telakkilerinin disiplinin ilişkisellik perspektifiyle yorumlanmasıdır. Buradaki basit mantık şudur: Din eğitimi insanın din ile ilişkisini inceleyen bir disiplin olarak kabul edildiğinde ele aldığı meseleleri bu ilişkideki işlevleri açısindan sorgulayarak kendi perspektifine uygun cevaplara ulaşabilir.

Bir soru biçimi olarak işlev, disiplinin kavramsal, kuramsal ve pratiğine ilişkin bütün hususlarda üzerine temerküz edilebilecek bir kavram görünümündedir. İslam düşüncesinde üretilen bilgilerin disiplindeki fonksiyonlarının kendisiyle tezahür edebileceği kanaatini taşıdığımız işlev ile kastedilen, oldukça geniş bir anlam yelpazesidir. Nitekim bu kavram böyle kapsayıcı bir anlamı hamletmeye de oldukça kabil görünmektedir. Zihinsel alana ilişkin işlev sorusu onun teorik ve pratik fonksiyonlarını açığa çıkarmaya muktedirken aynı şekilde pratik alana dair işlev sorusu da eylemin hem teorik hem pratik rolünü netleştirebilir.

Araştırmamızda bundan sonra yapılacak olan tevarüs ettiğimiz İslam düşüncesinin ürettiği bilgi mülahazalarının insanın din ile irtibatını kurmadaki işlevlerini sorgulamak olacaktır. Bu sorgulamadan tezahür eden anlamların din eğitimi için epistemolojik esaslar teşkil etmesi muhtemeldir. Bu amaçla öncelikle yukarıda aktarılan bilginin kaynaklarının işlevsellikleri bağlamında disiplinimiz için hangi fonksiyonları üstlenebileceği

\footnotetext{
${ }^{47}$ Her ne kadar din eğitiminin insanın din veya Allah ile ilişki hâdisesi, disiplinin de bu ilişkiyi inceleyen bir disiplin olduğu açıkça dile getirilmediyse bile bunu ima eden düşüncelerin "din" kavramı çerçevesinde takibi mümkündür. Bazı din eğitimcileri din kavramının disiplin açısından "insanın kutsalla ilişkisi" anlamında kullanılabileceğini savunmuştur. Bk. Beyza Bilgin, Eğitim Bilimi ve Din Eğitimi (Ankara: Ankara Üniversitesi İlahiyat Fakültesi Yayınları, 1988), 7; Muhiddin Okumuşlar-Fatih Genç, "Din Eğitiminin Bilimselleşmesi/Neliği", Din Eğitimi, ed. Recai Doğan - Remziye Ege (Ankara: Grafiker Yayınları, 2012), 53.
} 
incelenecektir. Sonrasında ise bütün bunların din eğitimi için oluşturabileceği epistemik perspektifin doğuracağı sonuçlar kaleme alınacaktır.

\section{DİN EĞİTIMİ AÇISINDAN AŞKIN VARLIKLA İLISŞKİ ARAÇLARI OLARAK BILGININ KAYNAKLARI}

Bir ilişkinin mahiyetinin ve keyfiyetinin tespit edilmesinin yolu öncelikle o ilişkiyi kuran araçların belirginleştirilmesinden geçer. Bu başlıkta İslam düşüncesinde bilginin kaynakları olarak kabul edilen unsurlar din eğitiminin bahsetmiş olduğumuz ilişkisellik ve işlevsellik perspektifinden ele alınacaktır. Disiplinimizin bu bakış açısı düşünce mirasımızda bilginin kaynakları olarak vazedilmiş idrak vasıtalarının insanın din ile ilişkisini kurmadaki işlevlerinin sorgulanmasını gerektirmektedir. Daha açık bir ifadeyle burada cevabı aranacak sorular "bilginin kaynakları söz konusu ilişkide herhangi bir fonksiyona sahip midir?" ve "sahip oldukları kabul edildiğinde bu fonksiyonlar din eğitimi için ne ifade eder?" olacaktır. Bu sorulardan hareketle İslam düşüncesinde bilginin kaynakları olarak belirlenen unsurların din eğitiminin bakış açısıyla "insanın din ile ilişkisini kuran araçlar/insanî kuvveler" olarak anlaşılmasının imkânı ortaya konulacaktır. Bir yandan din eğitiminin, ilim geleneğine uygun bir pozisyon almasını sağlayacak bu imkân diğer yandan onun diğer disiplinler arasından temeyyüz etmesini de temin edecektir. Bu, ayrıca İslam düşüncesindeki hâliyle zaten birçok açıdan problematiğe tabi tutulan bilgi kaynaklarının bir de insanın Allah ile irtibata geçmesinin olanakları olarak anlamlandırılması ve dolayısıyla geleneğin bugün hayatiyetini sürdürmesinin yolunu da açacaktır.

Yukarıdaki bilgilerden de anlaşılabileceği gibi ilimler kendi perspektifleri gereği, muhtelif unsurları bilginin kaynağı olarak kabul etmişlerdir. Ancak bu ihtilaflarla birlikte yine de nihai olarak bütün disiplinlerde bilginin kaynaklarının Kutsal ile ilişki kurmanın araçları şeklinde tasavvur edildiğini söylemek yerindedir. Kelam ile başlanacak olursa her ne kadar duyu organları ve doğru haber bilginin kaynakları olarak kabul edilseler de epistemolojik olarak daha çok öne çıkan, akıldır. ${ }^{48}$ Zira mevzuları itibariyle dinî, delilleri itibariyle insanî bir ilim kabul edilen kelâmın asıl amacı vahyi akılla yorumlamaktır. Farklı bir ontolojik varlık seviyesine tekabül eden gayb -dış duyular yoluyla algılanıp gözlem konusu olmadığı için insan aklının idrakinin dişında olmakla birlikte- vahiy vasıtasıyla aklın idrakine sunulabilir. Bu nedenle gayb mutlak anlamıla bilinemezliğini sürdürmekle beraber akıl tarafından anlaşılabilir/anlamlandırılabilir. ${ }^{49}$

$\mathrm{Bu}$ bağlamda -döngüsel olarak- vahiyden akla, akıldan tekrar vahye

${ }^{48}$ Abdülgaffar Aslan, "Kelam'da Aklın Epistemolojik Fonksiyonu", ed. Orhan Ş. Koloğlu vd., Kelam'da Bilgi Problemi (Bursa: Arasta Yayınları, 2003), 129.

${ }^{49}$ Ramazan Altıntaş, İslam Düşüncesinde İşlevsel Akıl (İstanbul: Pınar Yayınları, 2003), 12, 99. 
giden bir ilişkiden söz edilebilir. Vahiy öncelikle akıl tarafından temellendirilmekte, sonra aklın kullanılmasını gerekli kılarak onu meşrulaştırmaktadır. ${ }^{50}$ Dolayısıyla kelamî tasavvuruyla akıl vahiyden almış olduğu yetki ve bu yetkinin yine vahye yönelen bir şekilde kullanılmasıyla aslî yetkinliğine ve fonksiyonuna ulaşır. Akla veri sağlamakla yükümlü olan beş duyu organı ise kelâmın şâhidden gâibe biçiminde kurguladığı gaybî bilgiye ulaşmanın başlangıç noktasını ifade eder.

İslam felsefesinde ise -akla doğrudan veri sağlamadıkları ve aşkın alanla bizzat temasa geçemedikleri için- hâricî idrak güçlerinin işlevi bunun bir benzeridir. Zaman içerisinde aşınmaya, dönüşmeye müsait olmaları hasebiyle dış duyular ile henüz algı düzeyinde olup bilgiye dönüşmedikleri için bu duyuların elde ettiği veriler filozoflar tarafından çok fazla ihtimam görmez. Bu veriler ne zaman ki bâtınî duyu organlarından geçip akılla buluşursa o zaman küllî ma'kulat ve hakikî bilgi payesine sahip olur. İçsel duyulara ve dolayısıyla akla veri sağlamakla muavazzaf olmaları itibariyle dışsal duyuların ilişkideki görevi bu sebeple kelâmdaki gibi dolaylıdır.

Yukarıda sözü edilen işlevlerinden de anlaşılabileceği gibi bütün bâtıni idrak kuvveleri de doğrudan aşkın alanla ilişki kurma yetkinliğine sahip değildir. Bunlardan insanın kutsal alanla ilişkisini doğrudan kurmaya kabil olan sadece mütesarrife güçtür. Dış duyular yardımıyla algılanıp iç duyu organlarında işlenen veri ve bilgilerin nihaî durağı akıldır. Ancak İslam felsefesinde aklın fonksiyonu sadece hârici duyulardan elde edilen dışsal veya bâtıni idrak güçlerinin sağladığı içkin bilgilerin işlenmesi değildir. Onun bir de aşkın olanla iletişime geçme kabiliyeti vardır ki bunun felsefedeki adı ittisâl (birleşme)'dir. İşte bu kabiliyeti sayesinde insan Ruhu'l-Kudus (Hz. Cibril) ile irtibata geçer ve felsefenin en hakikî bilgi olarak kabul ettiği küllî ma'kulatı (tümel akledilenleri) elde eder.

Tasavvufa gelindiğinde ise -yukarıda da değinildiği gibi- özellikle ilk dönemleri itibariyle sûfînin, aklın müteâl varlıkla ilişki kurma kabiliyetine şüpheyle yaklaştığ1 müşahede edilir. Sûfîlere göre fizik dünyanın yaratılmış ve dolayısıyla "fakr" içinde bulunan bir varlığı olan aklın fizik ötesi ve yaratılmamış Mutlak Varlık'a dair sahih bir bilgi edinmeye salahiyeti yoktur. Dolayısıyla Hakk'ı tanımanın yegâne yolu O'nun kendini tanıtmasıdır. ${ }^{51}$ Sûfîlere göre Hakk'ın bilgilerinin tecelli ettiği mekân "kalb"tir. Bu durumda akıl sadece ait olduğu fizik dünyaya ilişkin bilgi edinme yetkinliğine sahipken, kalp, Latîf lütfettiğinde, aşkın varlık alanının bilgilerine muttali olabilir.

${ }^{50}$ Hülya Alper, İmam Mâtürîdî́de Akıl-Vahiy İlişkisi (İstanbul: İz Yayıncılık, 2009), 160.

${ }^{51}$ Cüneyd el-Bağdâdî'nin "Rabbimi Rabbimle bildim, O olmasaydı Rabbimi bilemezdim" sözü buna delalet eden bir örnektir. (Ebû Abrurrahmân es-Sülemî, el-Mukaddime fi'ttasavvuf, thk. Asım İbrahim el-Keyyâlî (Beyrut: Darü'l-Kütübi'l-i̇lmiyye, 2005), 15) 
Din eğitimi açısından bu ihtilafların ehemmiyeti, meselenin hakikî anlamda kimler ya da hangi disiplin tarafından tahkik edildiğinden ziyade söz konusu kaynakların insanın Kutsal'la münasebetini kurma imkânıdır. Dolayısıyla disiplin açısından önemli olan bu kaynakların bilgi edinme imkânları, şekilleri, süreçleri gibi hususlardan ziyade onların insanın Zât-1 Bârî ile ilişkisini kurma kabiliyetine ve zenginleștirmesine sâhip olup olmadıklarıdır. İslam düşüncesinde kendilerine yüklenen anlamlar ve görevler dikkate alındığında "insanın Mutlak Varlık'la ilişkisinin araçları/ kuvveleri" olarak muhtevalandırılması mümkün olan bilginin mezkûr kaynaklarının bu açıdan ilişkiyi doğrudan kuranlar ve dolaylı yoldan kuranlar şeklinde ikiye ayrılması olanaklıdır.

İnsanın Zât-1 Bârî’yle ilişkisini doğrudan kurmaya kabil olan sadece bâtıni duyulardan el-mutasarrife ile akıl ve kalptir. Teolojik bakış açısıyla vahiy ise -vahiy olması itibariyle- yukarıdan aşağıya bir yol takip etmesi sebebiyle Allah'tan insana yönelen bir ilişki tarzıdır. Nüzul olması hasebiyle teolojik bir ilişki biçimi olan vahiy din eğitimi nazarından ne zaman ki insan tarafından kendisiyle temasa geçilmesi yoluyla urûca (yükselme) dönüşürse anlam kazanır. Yani insan onunla etkileşime geçmediği takdirde vahiy "orada" dır ve "orada" olmaya devam ettiği sürece insan için bir ilişki vasıtasına dönüşmez. $\mathrm{O}$, insanın kendisine yönelmesiyle "şimdi" ve "burada" olma niteliklerine kavuştuğunda ancak insan için manidar bir ilişki aracına dönüşebilir. Başka bir tabirle Zât-ı Bârî'nin bizimle konuşması olarak vahiy teolojik değerlendirmeler için kullanışlı bir perspektif sağlamaya elverişliyse de insan bu konuşmaya kulak vermediği veya okuyarak onu kendisi için seslendirmediği, hayata geçirmediği müddetçe din eğitimi için insanın din ile ilişkisini kurmadaki fonksiyonunu icra etmiş sayılmaz. Bu sebeple nüzul olması itibariyle öznesi Münezzil (İndiren, Allah) olan vahiy din eğitiminde Aşkın Varlık'la ilişkinin araçlarından birisi değildir. Bu vasfa haiz olabilmesi için onun insan tarafından kendisine yönelinmek suretiyle bir nevi urûc vasıtasına dönüşmesi beklenir. Zira din eğitiminin konusuna dâhil olan meseleler doğrudan ve hakikî anlamda değilse bile insanın öznesi olduğu meselelerdir. Bir özne olarak insanın idrak anlaminda vahye yönelmesi de ancak yukarıda sözü edilen mutasarrife güç, akıl ve kalple mümkündür.

Bu iddia hiçbir surette insanın diğer bilgi kaynaklarının din eğitimi için herhangi bir işleve sahip olmadığı anlamını taşımaz. Yukarıda Câbirî'den naklettiğimiz İslam fikir geleneğinin üç kutupluluğu düşüncesiyle birlikte tasavvur edildiğinde diğer bilgi kaynaklarının bu ilişkideki hakikî rollerinin dolaylılığı tezahür eder. Aslı itibariyle İslam düşüncesinin temerküz ettiği insan-Allah ilişkisinin nihaî olarak fizik alanını tamamen dışarıda bırakmadığı izahtan varestedir. Dolayısıyla dış dünyaya taalluk eden bütün 
insanî idrak güçleri dolaylı bir biçimde din eğitimi için birer aşkın varlık alanıyla ilişki araçları olarak kabul edilebilir. Kelâmın görünür âlemden görünmeyene, İslam felsefesinin dış dünyadan içkin kuvveler olan bâtıni idrak güçlerine oradan da akıl ve aşkın varlık olan faal akla doğru seyreden güzergâhının iptidaî gereçlerini ifade eden hârici duyu organları bu anlamlıyla insanın dolaylı ilişki vasıtalarıdır. Ancak bunlar söz konusu dolaylılık çerçevesinde disiplinimizin sınırlarına dâhil olur. Yani mesela haricî idrak güçleri olan beş duyu organının âleme, âlem olması hasebiyle yönelmesi herhangi bir anlam ifade etmezken onunla Yüce Yaratıcı'nın birer ayetleri olarak geçilen her temas din eğitiminin alanına dâhil olur. Zaten hayatın her alanına nüfuz eden İslam söz konusu olduğunda varlık alanlarının birbirinden böyle kopuk bir şekilde mülâhaza edilmesi de mümkün değildir. O halde dini anlamanın, tecrübe etmenin birer aleti olarak kullanıldıklarında bütün bilgi kaynakları bizzat veya bilvasıta insanın gayb âlemiyle ilişkisinin birer araçlarına dönüşür.

Nihai olarak bütün bu bilgilerin bizi taşıdığı nokta İslam düşüncesinde bilginin kaynakları kabul edilen unsurların din eğitimi açısından insanın din ile ilişkisini kuran birer araç/kuvve olarak yorumlanmasının imkânıdır. Bunlar bazen insanın doğrudan ilişkisini kurmaya kabil iken bazen bu salahiyet dolaylı bir biçimde tezahür eder. Hangi veçheleriyle anlaşılırsa anlaşılsın kelâm ve İslam felsefesinin "akl" 1 , bâtınî idrak duyularından "mutasarrife güç" ve sûfî düşüncenin "kalb"i doğrudan bu irtibatı kurmaya muktedirken diğer bilgi kaynakları insanın dolaylı ilişki araçlarına tekabül eder.

Din eğitimi, perspektifi gereği bunlardan herhangi birisini tercih etmek, öncelemek veya aralarında hiyerarşik bir ast-üst ilişkisi kurgulamak durumunda değildir. Zira insan gibi âlemin nüshası kabul edilen çok yönlü bir varlık söz konusu olduğunda araçsal (işlevsel) mutasarrife gücün, aklın veya kalbin tek başına âlem ve Yaratıcıyla sahih bir ilişki üretemeyeceği açıktır. Böyle bir varlığın din ile ilişkisinin bütün veçheleriyle kuşatılması amacıyla disiplinin tavrı bunların hepsini insanın farklı kuvvelerini açığa çıkaran unsurlar olarak yekpare bir biçimde kabul etmektir. Bu araçlar bir bütün olarak aşkın varlık alanına kanalize edildiğinde bir yandan insanın fizik âleme ilişkin münasebetlerine değer yüklerken diğer yandan aslî yaratılış gayeleri olan ubudiyetin gereğine göre işlevlerini sürdürürler. Bunun aksine parçalayıcı ve ayırıcı bir bakış bu araçlardan herhangi birisinin mutlaklaştırılması riskini doğurur ki böyle bir nazarın insanı küllî bir biçimde anlamlandıramayacağı aşikârdır. Aklın mutlaklaştırılması pozitivist, mutasarrife gücün yegâneleştirilmesi hayalci, kalbin biricik kabul edilmesi ise bazen büsbütün spekülatif bilgi ve davranış geliştiren insan tipolojilerinin üretilmesi anlamını taşır. İnsanın bütün veçheleriyle hakikî bir şekilde varoluşunu gerçekleş- 
tirmesinin yegâne yolu bütün bu kuvvelerin bir bütün olarak koordineli bir biçimde işlevini sürdürmesidir. Pişgin'in tabiriyle "kalbin akledişi" ${ }^{52}$ şeklinde özetlenebilecek bu bütünlük hakikî imanın tahakkukunun da yoludur. Böyle kabul edildiğinde söz konusu araçların açığa çıkardığı bilgi türlerinin de çeşitlenmesi ve bu türlerin insanın din ile ilişkisinde tezahür eden bilme çeşitleri olarak anlamlandırılması da temin edilebilir.

\section{SONUÇ}

İslam düşüncesini oluşturan kelâm, İslam felsefesi ve tasavvufta bilgi; genellikle bilginin imkânları, tanımları, kaynakları ve türleri gibi bağlamlarda incelenir. Din eğitimi için epistemolojik bir zemin arayışının ürünü olan bu makale gelenekte bilginin kaynakları olarak sayılan dış duyular, iç duyular, doğru haber (Hz. Peygamber'in haberi ve mütevâtir haber), akıl ve kalbin disiplin için hangi anlamlara tekabül edeceğini sorgulamaktadır. Gelenekle, bilgiyle ilgili düşüncelerin üretilmesine yol açan bir saik olarak Kutsalla ilişki arka planında buluşması mümkün olan din eğitiminin bilginin kaynakları hususunda soracağı soru bu kaynakların insanın Kutsal ile ilişkisini kurmadaki işlevidir. Böyle bir sorunun açığa çıkardığı sonuç ise düşünce mirasımızda insanın idrak güçleri olarak mülahaza edilen bütün bilgi kaynaklarının disiplinimiz açısından insanın din ile ilişkisini kuran araçlara dönüştüğüdür. Zira İslam düşüncesinin insanın bilgi kaynakları/ kuvveleri olarak kabul ettiği mezkûr unsurların hepsinin doğrudan ya da dolaylı olarak insanın Kutsal ile ilişkisini kurma fonksiyonuna sahip olduğu görülmektedir. Bunlardan kelâmın "akl"ı, felsefenin "akl"ı ile bâtıni "mütesarrife güç" ü ve tasavvufun "kalb" i bu ilişkide doğrudan fonksiyoner bir yapı arz ederken, geriye kalan dış duyular ile bâtıni idrak kuvveleri insanı dolaylı olarak aşkın varlık alanına ulaştıran unsurlardır. Ancak doğrudan olmasa bile bunlar diğer idrak güçlerine veri sağlamakla mükellef olmaları itibariyle nihayetinde ilişkinin dolaylı araçları olarak değer kazanır. Onların bu durumu İslam düşüncesinin Allah-insan-doğa şeklindeki üçlü ilişkisinde insanın doğaya bakan veçheleridir. Kültürel mirasımızın insan-Allah ilişkisinde Allah'ın bir ayeti olarak konumlandırmak suretiyle doğayı araçsallaştırdığı gibi tabiata mürtebit dış duyular ile mütesarrife dışındaki iç duyular da onun bu fonksiyonuna benzer bir araçsal görev üstlenmektedir.

${ }_{52}$ Yasin Pişgin, "Kur'anda Kalbin Akledişi: İman”,Kelam Araştırmaları Dergisi (Kader) 11/2 (2013), 113-127. 


\section{KAYNAKÇA}

Ali, Muhammed. Akdül-ferâid 'alâ Şerhil-Akâid. Karaçi: el-Büşra, 2015.

Alper, Hülya. İmam Mâtürîdî̀de Akıl-Vahiy İlişkisi. İstanbul: İz Yayıncılık, 2009.

Altaş, Nurullah - Arıcı, İsmail. “Din Eğitiminin Bilimselleşme Süreci”. Din Eğitimi. ed. Mustafa Köylü - Nurullah Altaş. 48-79. İstanbul: Ensar Neşriyat, 2014.

Altıntaş, Ramazan. İslam Düşüncesinde İşlevsel Akıl. İstanbul: Pınar Yayınları, 2003.

Altun, Veysel. Din Eğitimi Açısından İnsanın Yetkinliği (Sadreddin Konevî Örneği). İstanbul: Marmara Üniversitesi, Sosyal Bilimler Enstitüsü, Doktora Tezi, 2020.

Âmidî, Seyfüddin. Ebkârül-Efkâr. thk. Ahmed Muhammed Mehdi. 5 Cilt. Kahire: Darü'l-Kütüb ve'l-Vesaiki'l-Kavmiyye, 2002.

Arslan, Z. Şeyma. Fıtrat Kavramı Çerçevesinde Ĕ̆itimde 'Insanın Neliği Sorusu'. İstanbul: Marmara Üniversitesi, Sosyal Bilimler Enstitüsü, Doktora Tezi, 2006.

Aslan, Abdülgaffar. "Kelâm'da Aklın Epistemolojik Fonksiyonu". Kelâm'da Bilgi Problemi. ed. Orhan Ş. Koloğlu. 129-138. Bursa: Arasta Yayınları, 2003.

Aydın, Muhammet Şevki. Din Ĕ̆itimi Bilimi. Kayseri: Kimlik Yayınları, 2017.

Bağdâdî, Abdülkâhir. Usûlü'd-dîn. Beyrut: Dârü'l-Kütübi'l-İlmiyye, 3. Basım, 1981.

Bâkıllânî, Ebû Bekr. Temhîdül-evâil ve telhisü'd-delâil. thk. 'İmâdüddin Ahmed Haydar. Beyrut: Müessesetü'1-Kütübi's-Sekâfiyye, 1986.

Başer, Hacı Bayram. Şeriat ve Hakikat: Tasavvufun Teşekkül Süreci. İstanbul: Klasik Yayınları, 2017.

Başkan, Feyza. Din Eğitimi Açısından Gazzâlî̀de Bă̆lanma Kavrayışı. İstanbul: Marmara Üniversitesi, Sosyal Bilimler Enstitüsü, Yüksek Lisans Tezi, 2018.

Batman, Elif. Din Eğitimi Açısından Hikmet Kavramı. İstanbul: Marmara Üniversitesi, Sosyal Bilimler Enstitüsü, Yüksek Lisans Tezi, 2016.

Bayraklı, Bayraktar. İslam'da Eğitim. İstanbul: y.y., 7. Basım, 2002.

Bilgin, Beyza. Eğitim Bilimi ve Din Eğitimi. Ankara: Ankara Üniversitesi İlahiyat Fakültesi Yayınları, 1988.

Bilgin, Beyza. Eğitim Bilimi ve Din Eğitimi. Ankara: Gün Yayıncılık, 2007.

Bulut, Nurgül. Din Ĕ̆itiminin İmkân ve Sınırlılıkları Açısından Mizâc Kavramı. İstanbul: Marmara Üniversitesi, Sosyal Bilimler Enstitüsü, Yüksek Lisans Tezi, 2013.

Bulut, Nurgül. "Evrensel Ahlâkın Ontolojisi; 'Öteki'de İçerlenmiş Ben”, II. Uluslararası Dini Araştırmalar ve Küresel Barış Sempozyumu. 1/234-353. b.y.: y.y., 2016.

Câbirî, Muhammed Âbid. Tekvinü'l-Aklil-Arabî: Arap Aklın Oluşumu. çev. İbrahim Akbaba. İstanbul: İz Yayıncılık, 1997.

Demirli, Ekrem. Sadreddin Konevî́de Bilgi ve Varlık. İstanbul: İz Yayıncılık, 2005.

Fakioğlu Bağcl, Hatice. Dewey ve Gadamer'in 'Tecrübe' Anlayışlarının Din Eğitimi Açısından Felsefi Olarak Incelenmesi. İstanbul: Marmara Üniversitesi, Sosyal Bilimler Enstitüsü, Doktora Tezi, 2019. 
Gazzâlî, Ebû Hamid Muhammed b. Muhammed. İhyâ'u 'ulûmi'd-dîn. 4 Cilt. Beyrut: Dârü'l-Ma'rife, 1983.

Gazzâlî, Ebû Hamid Muhammed b. Muhammed. İhyâ'u 'ulûmi'd-dîn. 5 Cilt. Beyrut: Dârü'l-Erkâm b. Ebi'l-Erkâm, 1998.

Gutas, Dimitri. İbn Sînâ'nın Mirası. çev. M. Cüneyt Kaya. İstanbul: Klasik Yayınları, 2010.

Gündüz, Muhammed Muhdi. Niyet Kavramının Din Eğitimi Açısından İncelenmesi (Gazzâlî Örneği). Mardin: Şırnak Üniversitesi Yayınları, 2019.

Gündüz, Muhammed Muhdi. "Niyet Kavramı ve Din Eğitimi Açısından Anlam Katmanları”. Siirt Üniversitesi Illahiyat Fakültesi Dergisi 6/2 (Aralık 2019), 301-332.

Hanefi, Hasan. "Müslüman Aklının Eleştirisi ya da İslam düşüncesinin Yeniden İnşası". Uluslararası İslam Düşüncesi Konferansı 2. 116-129. İstanbul: İstanbul Büyükşehir Belediyesi Kültür İşleri Daire Başkanlığı Yayınları, 1997.

Hücvîrî, Ebü'l-Hasen Alî b. Osmân b. Ebî Alî el-Cüllâbî. Keşfül-mahcûb. thk. İs'ad Abdülhadi Kındil. Beyrut: Dârü'n-Nehdati'l-Arabiyye, 1980.

İbn Sînâ, Ebû Alî Hüseyn b. Abdillâh b. Alî. de Anima. thk. Fazlurrahman. Durham: University of Durham, 3. Basım, 1970.

İbn Fûrek, Ebû Bekr Muhammed, Mücerredmakalâti'ş-Şeyh Ebil-Hasan el-Eş'arî. thk. Daniel Gimaret. Beyrut: Dârü'1-Meşrik, 1986.

İzmirli, İsmail Hakkı. Yeni İlm-i Kelâm. haz. Sabri Hizmetli. Ankara: Umran Yayınları, 1981.

Karadaş, Cağfer. "Birleşen ve Ayrışan Yönleriyle Kelâm İlminin Usûl-i Fıkıh, Tasavvuf ve İslamFelsefesi ile Olan İlişkisi". İslam Düşüncesinin Kurucu Unsurları: Usûl-i Fıkıh, Kelâm, Tasavouf ve İslamFelsefesi (Tartışmalı İlmî İhtisas Toplantısi). 19-67. b.y.: y.y., 2016.

Kaya, M. Cüneyt. “Önsöz”, İbn Sînâ'nın Mirası. mlf. Dimitri Gutas. İstanbul: Klasik Yayınları, 2010.

Kelâbâzî, Muhammed b. İbrâhim. et-Ta'arruf li mezhebi ehli't-tasavvuf. thk. Ahmed Şemsüddîn. Beyrut: Dârü'l-Kütübi'l-İlmiyye, 2001.

Kindî, Ebû Yûsuf Ya'kûb b. İshâk. Felsefî Risaleler. çev. Mahmut Kaya. İstanbul: Türkiye Yazma Eserler Kurumu Başkanlığı, 2015.

Kindî, Ebû Yûsuf Ya'kûb b. İshâk. "Kitâbün fi felsefeti'l-ûlâ" Risâletü'l-Kindî elfelsefiyye. thk. Muhammed Abdülhâdî Ebû Rîde. Kahire: Dârü'l-Fikri'lArabi, 1950.

Kindî, Ebû Yûsuf Ya'kûb b. İshâk. "Risâletü'l-Kindî fi hudûdi'l-eşyâ-i ve rusûmihâ"

Risâletül-Kindî el-felsefiyye. thk. Muhammed Abdülhâdî Ebû Rîde. Kahire: Dârü'1-Fikri'l-Arabi, 1950.

Kuşpınar, Bilal. İbn Sina'da Bilgi Teorisi. İstanbul: MEB Yayınları, 1995.

Kutluer, İlhan. Yitirilmiş Hikmeti Ararken. İstanbul: İz Yayıncılık, 2011.

Mâtürîdî, Ebü'1-Mansûr. Kitâbü't-Tevhîd. thk. BekirTopaloğlu-Muhammed Aruçi. Ankara: TDV İSAM Yayınları, 4. Basım, 2018.

Nasr, Seyyid Hüseyin. Bilgi ve Kutsal. çev. Yusuf Yazar. İstanbul: İz Yayıncılık, 1999. 
Okumuşlar, Muhiddin - Genç, Fatih. “Din Eğitiminin Bilimselleşmesi/Neliği”, Din Eğitimi. ed. Recai Doğan - Remziye Ege. 53-104. Ankara: Grafiker Yayınları, 2012.

Özalp, Ahmet. "Dâvûd el-Kayserî Açısından Din Eğitiminde Bir Dönüşüm Hâdisesi Olarak Karanlık ve Aydınlık". IV. Türkiye Lisansüstü Çalışmalar Kongresi Bildiriler Kitabı-V (Felsefe-Ĕgitim-İletişim). ed. Hümeyra Dinçer Ümit Güneş. 4/179-194. İstanbul: y.y., 2015.

Özalp, Ahmet. Din Eğitimi Açısından Dâvûd el-Kayserî'de İnsan Kavrayışı. İstanbul: Marmara Üniversitesi, Sosyal Bilimler Enstitüsü, Yüksek Lisans Tezi, 2014.

Özcan, Hanifi. Mâtürîdî'de Bilgi Problemi. İstanbul: İFAV Yayınları, 6. Basım, 1998.

Özervarlı, M. Sait, “Alâeddin el-Üsmendî’nin Kelâmcllı̆̆ı ve Bilgi Teorisi: Mâverâünnehir Kelâm Düşüncesine Bir Katkı".'Islam Araştırmaları Dergisi 10 (2003), 39-63.

Pezdevî, Ebü'l-Yüsr. Usûlü'd-dîn. thk. Hans Peter Linss. Kahire: Dâru İhyai'lKütübi'l-Arabiyye, 1963.

Pişgin, Yasin. “Kur'anda Kalbin Akledişi: İman”. Kelam Araştırmaları Dergisi (Kader) 11/2 (2013). 113-127.

Râzî, Fahrüddîn. Şerhül-Işârât ve't-tenbîhât: Felsefe, tabi'iyyât, ilahiyyât ve 'irfân. thk. Ali Rıza Necefzade. Tahran: Encümen-i Asar ve Mefahir-i Ferhengi, 2005.

Sühreverdî, Ebü'l-Fütûh Şihâbüddîn Yahyâ b. Habeş. "el-Elvâhü'l-'imâdiyye". Mecmua-i musannefât-i Şeyh-i İşrâk. 31-98. Tahran: Pejûheşgâh-1 Ulûm-i İnsânî ve Mütâlaât-i Ferhengi, 2001.

Sülemî, Ebû Abrurrahmân. el-Mukaddime fi't-tasavouf. thk. Asım İbrahim elKeyyâlî. Beyrut: Darü'l-Kütübi'l-İlmiyye, 2005.

Tabâtabâî, Seyyid Muhammed Hüseyin. Şerhu bidâyeti'l-hikme. thk. Muhammed Mehdi el-Mü'min. 2 Cilt. y.y.: Mektebetü'l-Fikr, 1422/2001.

Teftâzânî, Sa'düddîn. Şerhü'l-'akâidi'n-Nesefiyye. Karaçi: el-Büşra, 2015.

Tehânevî, Muhammed b. 'A'la b. 'Ali el-Fârûki el-Hanefi. "İlm”. Keşşâfu istilâhâti'tfünûn. Beyrut: Dârü'-Kütûbi'l-İlmiyye, 3. Basım, 1998.

Tirmizî, Hakîm. Beyânül-fark beyne's-sadr ve'l-kalbvel-fu'âd ve'l-lüb. thk. Nicholas Lawson Heer. Kahire: Dâru İhya'i'l-Kütübi'l-Arabiyye, 1958.

Tunçbilek, Hasan Hüseyin. "Bilgi Kaynağı Olarak Haber-i Sâdık”. Harran Üniversitesi Illahiyat Fakültesi Dergisi 5 (2006), 83-140.

Türker, Ömer. İbn Sînâ'da Metafizik Bilginin İmkânı. Ankara: TDV Yayınları, 2. Basim, 2019.

Türker, Ömer. “Mukaddime'de Aklî İlimler Algısı:İbnHaldûn'un ‘Bireysel Yetenekler' Teorisi". İslam Araştırmaları Dergisi 15 (2006), 33-50.

Uludağ, Süleyman. “Kalp”. Tasavvuf Terimleri Sözlüğü. İstanbul: Kabalcı Yayıncılık, 2012. 